DIW BERLIN

Discussion

Papers
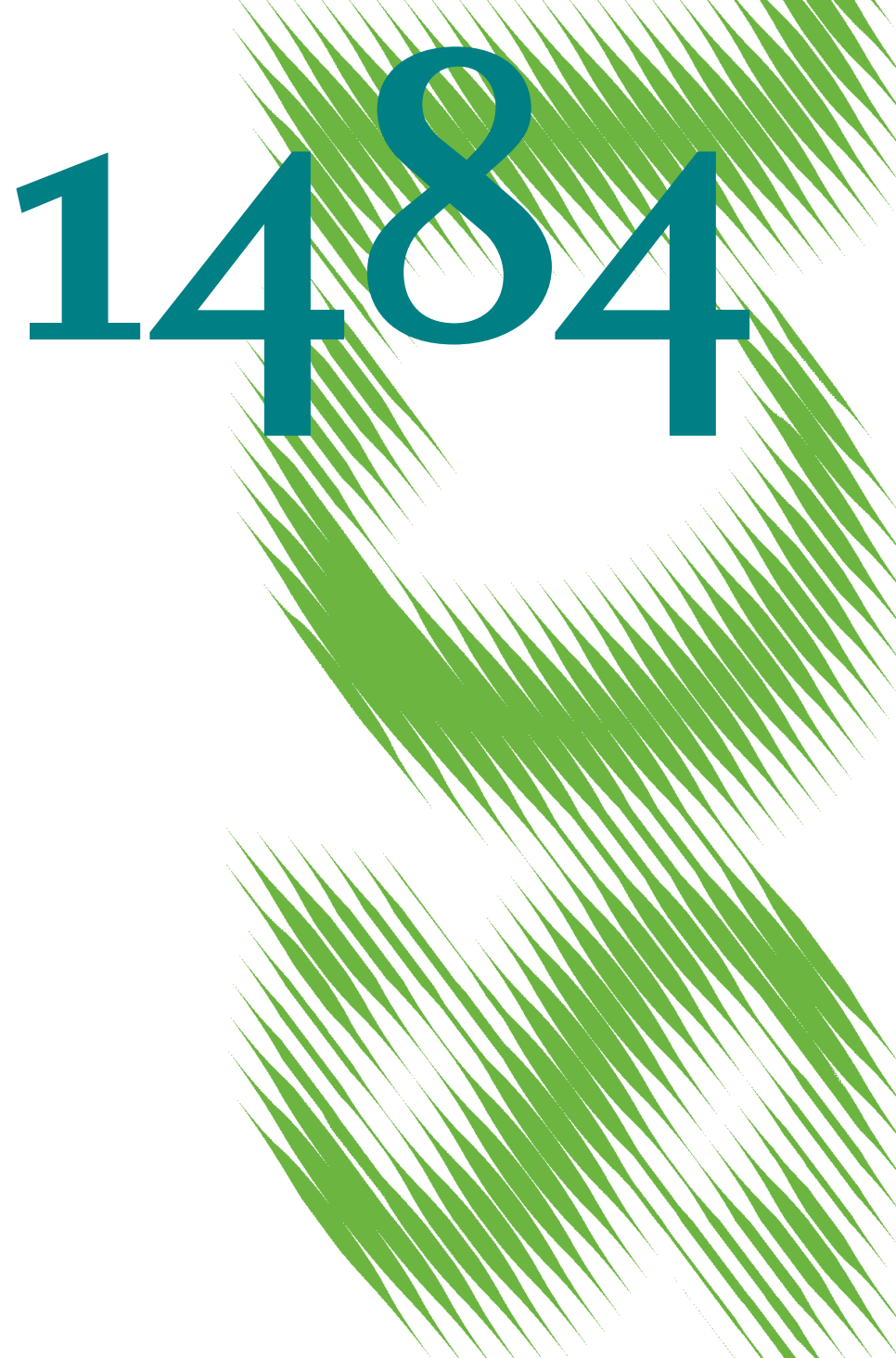

Are Ethical and Social Banks Less Risky?

Evidence from a New Dataset 
Die in diesem Papier vertretenen Auffassungen liegen ausschließlich in der Verantwortung des Verfassers/der Verfasser und nicht in der des Instituts.

IMPRESSUM

(C) DIW Berlin, 2015

Deutsches Institut für Wirtschaftsforschung

Mohrenstr. 58

10117 Berlin

Tel. +49 (30) $89789-0$

Fax +49 (30) $89789-200$

http://www.diw.de

ISSN elektron. Ausgabe 1619-4535

Die Diskussionspapiere können kostenfrei von der Webseite des DIW Berlin heruntergeladen werden: http://www.diw.de/discussionpapers

Die Diskussionspapiere des DIW Berlin werden in RePEc und SSRN indexiert:

http://ideas.repec.org/s/diw/diwwpp.html

http://www.ssrn.com/link/DIW-Berlin-German-Inst-Econ-Res.html 


\title{
Are ethical and social banks less risky? Evidence from a new dataset.*
}

\author{
Marlene Karl
}

April 2015

\begin{abstract}
This paper introduces a new and comprehensive dataset on "alternative" banks in EU and OECD countries. Alternative banks (e.g. ethical, social or sustainable banking) experienced a recent increase in media interest and have been hailed as an answer to the financial crisis but no research exists on their stability. This paper studies whether alternative banks differ from conventional banks in terms of riskiness. For this I construct a comprehensive dataset of alternative banks and compare their riskiness with an adequately matched control group of conventional banks using mean comparison and panel regression techniques. The main result is that alternative banks are significantly more stable (in terms of z-score) than their conventional counterparts. The results are robust to different estimation methods and data specifications. Alternative banks also have lower loan to asset ratios and higher customer deposit ratios than conventional banks.
\end{abstract}

Keywords: Ethical banking, social banking, bank risk, financial crisis

JEL Codes: G21, G32, E44, M14

* Contact: mkarl@diw.de. DIW Berlin and Institut für Wirtschaftsforschung Halle, Germany. I am grateful to Dieter Nautz, Claudia Buch, Franziska Bremus, Caterina Giannetti, Maximilian Podstawski, Johannes Steinbrecher and the participants of the 2014 Halle Financial Markets Workshop, the Bologna Workshop on Social Economy for Young Economists, the DIW GC Summer Workshop and the 4. Workshop Banken and Finanzmärkte in Eltville by the Universities Augsburg, Magdeburg and the Deutsche Bundesbank for helpful 4. Workshop Banken and Finanzmärkte in Eltville by the Universities Augsburg, Magdebuts
comments. The views and opinions expressed in this article are only those of the author. 


\section{Introduction}

Following the worldwide financial crisis that started in 2007, ethical and social banks have received increased and favorable attention in the media and by depositors. Their growing clientele sees them as a possible answer and reaction to the financial crisis (Weber and Remer, 2011). Mainly due to their increased popularity with small depositors ethical banks in Europe have doubled their assets between 2007 and 2010 (Benedikter, 2011). However, no comprehensive empirical evaluations of these banks exists. The small literature on social banking offers a few general descriptions of the business model of social banks (Benedikter, 2011; Weber and Remer, 2011) but there exists no comprehensive study that I am aware of that evaluates the stability of alternative banks in comparison to conventional banks. This may be due to the fact that despite their rapid growth, banks with an alternative business model remain a niche phenomenon and their impact on the financial system is accordingly small. Since the importance of social banks has nevertheless increased in the last few years and may continue to rise (Köhler, 2010), this paper aims to fill this gap in the literature by providing a comprehensive analysis of the behavior of alternative banks in EU and OECD countries, especially during and since the financial crisis.

In the context of this paper the focus of the analysis lies on two areas of interest from the perspective of financial stability. First, bank riskiness and second, bank outcomes in the global financial crisis. Concerning the first point, bank riskiness, from a theoretical perspective, alternative banks could be more or less risky than conventional banks. On the one hand, alternative banks could be less risky as they are generally risk-averse, focused on the real economy and tend to avoid speculative activities. On the other hand, alternative banks could be more risky, if, for example, they generate less profits that can be used to re-build capital buffers after crisis events or they may be exposed to higher credit default risk if the "worthy causes" among their borrowers are not financially sound. In the second area of research, the development of alternative banks in and since the financial crisis, there are also two simultaneous effects. First, alternative banks are exposed to the general adverse effects of a troubled economy, second, they experience a period of accelerated growth due to an increase in customer deposits. Although most 
social banks did very well during the financial crisis, their rapid growth since could be a threat to their business model (Remer, 2011). For example, a strong influx of deposits may be difficult to match with a sufficient number of borrowers that fulfill the two criteria of being social or ethical as well as financially sound.

Accessing a large variety of sources, I develop a first and comprehensive overview of alternative banks in EU and OECD countries. I use balance sheet data from Bankscope to empirically evaluate their stability. Methodologically, I follow the literature on the evaluation of Islamic banking (see e.g. Beck et al., 2013; Čihak and Hesse, 2010) in comparing conventional and alternative banks. I match the alternative banks with a comparable set of conventional banks by size, country of origin, type of bank (commercial, savings or cooperative) and years of data observed. Matching is based on year 2006 , that is, before the outbreak of the global financial crisis.

The main result is that alternative banks are significantly more stable than their conventional counterparts. This result is robust to different estimation methods and data specifications. Following the outbreak of the global financial crisis alternative banks also experienced a rapid growth in deposits and total assets. This occurred simultaneously with potential negative effects of the financial crisis. Therefore the effects of the crisis on bank stability are not easily distinguishable from the effects of the inflow of deposits. Results for the effects of the financial crisis on the stability of alternative banks are therefore less clear-cut.

This paper contributes to the literature on social and ethical banking in several ways. It introduces a comprehensive dataset of alternative banks and it matches alternative banks with an appropriate control group of conventional banks. This dataset is then used to address two research questions. First, it evaluates if alternative banks differ from their conventional counterparts in terms of risk. Second, it studies the stability and growth of alternative banks during and since the global financial crisis.

The remainder of this paper is organized as follows. Section 2 develops a definition of alternative banking, introduces the related literature and explores theoretically how the riskiness of alternative banks may differ from conventional banks. Section 3 describes the alternative bank dataset and the matching of the conventional bank control group. 
Section 4 presents regression results on bank stability and robustness tests. Section 5 concludes. A detailed methodological section may be found in the appendix.

\section{Alternative banking and stability}

\subsection{Definition of an alternative bank}

This paper defines "alternative banks" as those banks that pursue ethical, social, sustainable, environmental or other "added social value" goals as a core part of their business strategy. Banks with religious affiliations or roots are included as well if they follow a special code of ethics, engage in preservation of the environment or make similar adjustments to their business model.

The related literature offers no consistent terminology. Often, the terms "ethical" or "social" are used to discuss the same banks. I resort to the more general umbrella term "alternative" but also use the terms "ethical" or "social" when referencing specific literature. The above definition of alternative banks is close in spirit to Weber and Remer (2011, p.2) who define "social banking as banking that aims to have a positive impact on people, the environment and culture". Many social banks follow a "dual bottom line" approach, that is, in their business decisions they aim for their own benefit as well as the benefit of the society. This can mean, for example, that they extend credit according to ethical or environmental criteria. San-Jose et al. (2011) find that the the hallmark of an "ethical" bank is that it is striving for economic and social profitability, that is, having a dual bottom line.

These definitions show that there is some heterogeneity among alternative banks. They have different origins such as social reform movements, environmental preservation movements, or may hold themselves to ethical, christian or anthroposophical values (see Weber and Remer, 2011 for an overview). Although alternative banks have these different origins and have varying ways of doing business there is one unifying characteristic that makes it possible to group them together for analysis: This is their (explicit or implicit) dual- or triple bottom line approach which implies that alternative banks 
have different goals than conventional banks.

For the purpose of this study, I exclude banks engaging in microfinance, alternative banks in developing countries, and guarantee or business-development banks. Although they do share some characteristics with the alternative banks, they operate in completely different business environments. Alternative banks must further be distinguished from savings banks or cooperative credit unions which were also originally founded in the spirit of helping their members or disadvantaged groups in general. Although, today most savings and cooperative banks do not explicitly take ethical considerations into account, many alternative banks are organized as cooperatives and there may exist some overlap with this banking type. To account for this, the banking type of the alternative banks (commercial, savings or cooperative) is controlled for in the further analysis. The country of origin of the bank is also controlled for, because characteristics of, for example, cooperative banks, also differ between countries.

\subsection{Related literature}

Although the global financial crisis drew much attention toward sustainable forms of banking and spurred interest in social banking in general society, the academic literature on social banking remains very small. This is also due to the very small size of the alternative banking sector. In Germany, for example, social and ecological banks have a market share of $0.2 \%$ of the private banking sector but 16 million of Germans are potentially interested in these types of banks (zeb, 2012). As alternative banks are seen as one answer to the financial crisis, this warrants study of their stability.

Weber and Remer (2011) provide an overview and introduction into social banking with descriptions of the history, business environment and challenges of social banks, while Benedikter (2011) discusses social banking against the backdrop of the financial crisis. Empirical studies that analyze multiple social banks do not exist as of yet, with the sole exception of Scheire and De Maertelaere (2009) who analyze the business models of social banks that are members of an association of social banks, the Global Alliance for Banking on Values (GABV). They provide an overview of the business strategies and balance sheets of 12 social banks that are GABV members for 2007 and 
2008, finding that ethical banks are highly financed by deposits but do not always succeed in transforming these in loans. They do not, however, compare social banks with (appropriately matched) conventional banks. Most other literature on alternative banking studies individual banks only (e.g. Becchetti and Garcia, 2008; Harvey, 1995). The relatively small size of the empirical ethical banking literature may also be due to several methodological challenges: first, no comprehensive overview of alternative banks exists, second, the econometric problems posed by their small sample size, and third, the question of an appropriate control group.

The methodological challenges to studying alternative banks are similar to those of studying Islamic banking. While for the former, to the best of my knowledge, no papers that compare between banking groups exist, the latter is studied in the academic literature. Specifically, the performance of Islamic banks during the financial crisis received attention in several studies (Bourkhis and Nabi 2013; Hasan and Dridi 2011). Islamic banks are comparable to social banks in that they both subscribe to a certain set of (religious or moral) rules that constrain their behavior and may differentiate them from conventional banks in a number of ways. In both cases there are religious or ethical/moral motivation for the bank's actions. Some similarities in the study of Islamic banks and social banks are that they have less or no focus on interest rates, that they are a small but quickly growing sector and that their business model differs from conventional banks. The methodological challenges are also similar due to the limited number of alternative banks which leads to few observations and the question of the choice of a suitable control group. That is why this paper takes a similar methodological approach as some of the Islamic banking literature. Specifically, I rely on matching to obtain a comparable group of conventional banks (Bourkhis and Nabi, 2013) and use of robust estimation techniques (Čihak and Hesse, 2010).

\subsection{Riskiness and stability of alternative banks}

\section{Riskiness of alternative banks}

From a theoretical perspective, alternative banks could be more or less risky than conventional banks. In general, alternative banks are relatively risk-averse and serve pri- 
marily the real economy. They avoid risky activities, such as highly structured financial products and speculative proprietary trading. They may also hold larger capital buffers than do their conventional counterparts. Several of the ethical and social banks studied here are organized in a network of banks that follow sustainable standards, the Global Alliance for Banking on Values (GABV). Members of the GABV must comply with their "sustainable banking principles". These include among others the triple-bottom line approach ("profit, people, planet"), serving the community and the real economy, focusing on long-term relationships with clients, transparency and a long-term, selfsustaining business model ${ }^{1}$. These principles demonstrate that alternative banks aim to engage in little risk taking but they could still be equally risky or riskier than conventional banks because they may be subjected to unique risks stemming from their business model.

Social banks may be exposed to higher credit default risk and concentration risk due to the specialized nature of their lending. For example, an environmental bank that grants a lot of credit to the renewable energy sector would be strongly affected by the curtailment of renewable energy subsidies. Also, some of the ethical lending might be inherently riskier as these "worthy causes" could be less well capitalized than typical borrowers. Then again, alternative banks are specialists in their field and therefore possess specific know-how that allows them to correctly assess the riskiness of a project. They are skilled in monitoring these creditors and some alternative banks provide business advice to their creditors that could lower riskiness, especially with inexperienced creditors (e.g. small and medium enterprises, first-time home buyers). Supporting this line of thought, Acharya et al. (2006) find that a sectoral specialization of banks is linked to better monitoring and higher quality of the loan portfolios. Additionally, social banks also engage in relationship lending that lessens information asymmetries. Also, as the customers of alternative banks chose their bank specifically for its ethical or social business strategy, the reputation risk of an alternative bank is likely to be higher than that of a conventional bank. The higher potential costs of a scandal should lead to more prudent business decisions and a clear focus on compliance.

It is a challenge for alternative banks to find highly qualified personnel who identify

\footnotetext{
${ }^{1}$ Sustainable Banking Principles are summarized from www.gabv.org
} 
with the banks' values (von Passavant, 2011). The possibility exists that some of the employees of social banks have little experience in financial business and risk management. Employees and management of social banks usually accept wages that are below the industry average and bonus payments are small or nonexistent. This eliminates moral hazard and should lead to greater risk-aversion as well as less procyclical lending behavior than in conventional banks.

The stability of the bank can also be affected by its ability to generate profits. As alternative banks have other objectives besides generation of profit, it is likely that their profitability will be lower than that of conventional banks. One determinant of bank profitability is the interest rates setting of alternative banks. These are not purely set according to refinancing costs and risk premia, but also take social or environmental considerations into account. In alternative banks, interest rates are often, at least partially, set according to social standards. For example, Cornée and Szafarz (2013) present data on business loans made by a French alternative bank and show that the bank charges interest rates that are below market rates for loans to social projects. While this furthers the social goals of the bank, it may also have less capacity to build up capital buffers or re-build capital after adverse events. Still, part of this loss of interest income may be offset by the banks customers who also receive lower interest payments on their deposits. Two recent surveys explore the interest rates and riskiness of ethical banking in Germany. A survey study by the management consultancy zeb (2012) finds that German residents state that they would forgo $1.3 \%$ in remuneration to invest their money ethically. Irrespective of the questionable reliability of survey answers, one can state that clients of an ethical or social bank make a conscious choice to place their money there and are willing to forgo some part of their remuneration. A survey of German financial experts finds that these believe that social banks take fewer risks (Köhler, 2010). To summarize, there are multiple factors that could lead alternative banks to be more risky or less risky than conventional banks and these factors could balance each other out.

\section{Stability of alternative banks in the global financial crisis}

The stability of social banks during and since the financial crisis is of special interest due 
to the view that alternative banks could be an answer to the financial system fragility made apparent in the global financial crisis (Fessmann, 2013). There exist multiple and simultaneous channels through which the global financial crisis may have affected the stability of alternative banks. First, through the interbanking system and worsening financial markets conditions. Second, through the recession in the real economy. Third, through the rapid influx of customer deposits since the outbreak of the crisis.

Concerning the first channel, as alternative banks are predominantly financed by small depositors and largely independent from the interbank market (Scheire and De Maertelaere, 2009) they are mostly shielded from contagion and should therefore be more stable in times of crisis. They do not engage in speculative activities which could incur high losses in market downturns. Second, in real terms, alternative banks should enjoy greater stability than their conventional peers due to their emphasis on relationship lending, long-term funding and refusal to engage in high-risk business. Some of their lending, for example to social projects (pre-schools etc.) is less exposed to the business cycle than the manufacturing sector but may also be particularly affected in case of public spending cuts. Although most social banks emerged strengthened from the financial crisis (Remer, 2011), they were not immune to economic developments. For example, two of the 12 banks studied in Scheire and De Maertelaere (2009) no longer exist as of 2014 .

Concerning the third channel, before the crisis ethical and social banking was mainly a niche phenomenon. Their rapid growth since then could be a threat to their business model. In conventional banks, strong growth of credit volume is associated with heightened bank risk (Köhler, 2015). This could lead to difficulties if the organizational structure of the banks are not equipped to handle this rapid influx of deposits. Also, rapid growth could destabilize the banks and pose a threat of dilution of core principles and values if, for example, not enough socially beneficial and economically sustainable projects can be found to match the increased inflow of deposits. Remer (2011) notes that this may be the case for some social banks. Specifically, in economically uncertain times and in a low interest-rate environment, a sudden increase in deposits and therefore total assets cannot immediately be translated in revenuegenerating loans or other investments. Social banks find it more difficult to obtain 
equity capital than to obtain deposits (Becchetti, 2011). With capitalization remaining constant, capitalization-based risk-measures (leverage, z-score) will automatically report an increase of the banks riskiness.

\section{Data and Methodology}

\subsection{A new dataset of alternative banks}

\section{Comprehensive list of alternative banks}

To the best of my knowledge, this is the first paper that studies alternative banking in OECD and EU countries using a comprehensive set of banks. In a first step, a comprehensive list of banks that are identified or self-identify as alternative is compiled using a large number of sources. A first source are the umbrella organizations (GABV, INAISE, FEBEA) that represent some of the social and ethical banks. Second, I obtain banks from the social banking literature, for example an overview of social saving initiatives by the Réseau Financement Alternatif (2006) and case studies of ethical and social banks. Third, several dedicated websites (e.g. banksdaily.com) containing bank lists and bank overviews, websites of the banks themselves that often contain links to partnering banks and news sites are searched for keywords. Fourth, web searches of news sites and internet archival services yield information on alternative banks that are no longer active. Fifth, the websites of active alternative banks are scanned for defunct alternative banks by going through information on past mergers and acquisitions. Further, the websites are checked for joint ventures or daughters that are also alternative banks. Sixth, all banks available in the Bankscope database are searched for specific keywords or strings that are often contained in the names of alternative banks (e.g. "etic"). As these different approaches yield a large overlap of banks, I feel confident that my final dataset includes the vast majority of alternative banks ${ }^{1}$. When available, the dataset of alternative banks contains name, type, founding year, information on past mergers, and, if applicable, the year activity ceased.

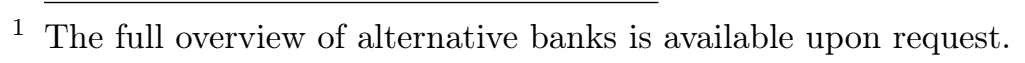


Since the increase in popularity of social or ethical banking following the global financial crisis, one concern with the classification of alternative banking may be the threat of green-washing. There is the possibility that terms like "ethical" or "sustainable" are used mainly for marketing purposes. Ordinary commercial banks may seek to improve their reputation by publically announcing ethical standards that are mainly geared towards the media and potential customers. The credibility and efficiency of these announcements may then be doubtful. In the construction of the alternative bank dataset, special care is paid to weed these banks out. Specifically, a bank can only be included in the group of alternative banks if it clearly states that its business model is substantially changed through its convictions. That is, the bank implicitly or explicitly has a dual bottom line. One possible caveat when relying on information collected from bank websites (CSR reports, mission statements, bank self descriptions) to obtain the information on bank characteristics and behavior, might be that banks simply do not distribute information about the social or ethical behavior they engage in. However, as banks have an incentive to inform their clients and potential clientele about their services and unique selling points (according to the principle "Do good and talk about it"), they have an incentive to provide detailed information about the implementation of their ethics guidelines. That is why it is reasonable to assume that if a bank does not mention a specific type of alternative or socially desirable behavior, it does not engage in it.

Therefore, banks are only included in the list if their ethics guidelines are strict and comprehensive enough to actually change the business structure of the bank. This may for example be the case if the bank is turning down business opportunities or avoiding market segments due to ethical considerations. Each bank website is checked individually for the manner in which the banks values manifest in the business model. In case of banks that are no longer active, I resort to alternative information sources such as newspaper articles or internet archives.

For the banks included in the alternative bank dataset, this "alternative" behavior can take many different forms. Many banks adapt their investment and their lending to their business goals. Some have negative lists, that exclude certain areas of business from their activity, while others have positive lists and may, for example, only lend to 
socially or environmentally beneficial projects. Many of the alternative banks are very environmentally conscious, for example, they use exclusively renewable energy sources, compensate their $\mathrm{CO}_{2}$ emissions or regularly audit their use of resources. Several alternative banks pursue their goals through the setting of interest rates. The interest rate on loans may be partially determined by the type of project financed. Discounts are given to social projects or ecological building renovations. Customers may also, for example, choose to forgo part of the interest rates they would receive on deposits to provide social or ecologial projects with subsidized interest rates on loans. While most banks seek to be profitable, some explicitely state that they do not seek to maximize their profit. Often, part of the profit is donated. Employee remuneration may be competitive but may also be lower than in conventional banks. To stave off excessive payments to management, some banks define a maximum spread between highest- and lowest-earning employees while other banks make no or quite small bonus payments. These findings complement the work by San-Jose et al. (2011) who discuss the problem of identifying banks that are "truly" ethical and identify characteristics that distinguish ethical banks from conventional banks. They conclude that ethical banks distinguish themselves through high transparency and allocation of assets to create additional social profit.

\section{Data sources and description}

The final list of banks contains 65 banks. For 54 of these multiple years of balance sheet data are available in Bankscope ${ }^{1}$. The database may contain unconsolidated as well as consolidated bank balance sheets from the same bank. This could lead to double counting (see e.g. Buch and Neugebauer, 2011). The alternative banks in Bankscope have the consolidation codes C1 (consolidated statement without unconsolidated companion), C2 (consolidated statement with unconsolidated companion) and U1 (unconsolidated statement with no consolidation companion in Bankscope). Other consolidation codes such

1 This excludes 15 alternative banks based in the US that do not have, unfortunately, balance sheet data is available in Bankscope. This is due to the fact that Bankscope focuses on the larger banks in each country. While it might be conceivable to supplement the US data using regulatory data provided by the FDIC (Call Report Data), the Bankscope balance sheet data is treated to achieve comparability across different accounting standards. The US regulatory data remains in the original format, thus introducing a source of bias. Also, as banks in the United States were at the epicenter of the financial crisis their riskiness might not be comparable to alternative banks overall. 
as U2 (unconsolidated statement with consolidated companion in Bankscope) are not present, which means that there is no danger of double counting of alternative banks. In the construction of the conventional comparison group I similarly use only these the consolidation codes C1, C2 and U1. This specification follows a suggestion by Duprey and Lé (2014) and includes banks at their highest available consolidation status. All balance sheet data are in million USD and the Bankscope universal model data format is used. The data in the universal format is intended to facilitate comparability accross different countries and accounting standards (Fitch Ratings and Bureau van Dijk, 2009).

The final dataset spans the years 1997 through 2012; however, the panel is quite unbalanced due to bank failures, mergers and acquisitions, as well as the representation of new banks in Bankscope. In order to achieve a reasonably balanced panel and allow the analysis of the effects of the global financial crisis, only banks that have balance sheet data available during the years 2006-2009 are included in the further analysis. There are 34 banks for which balance sheet data is available from 2006-2009 and that are used for the subsequent matching process. Some of the alternative banks do not have data available for the years 2006-2009 due to mergers and acquisitions or cease of activity as a bank. Most alternative banks that lack sufficient data were active during that time, but their balance sheets are not represented in Bankscope. These tend to be the comparatively smaller banks as well as relatively young banks. This could potentially be the source of some bias, however, it is unlikely that the inclusion into the Bankscope database differs systematically between alternative and conventional banks.

\subsection{Control group of conventional banks}

As alternative banks make up only a tiny fraction of the banking market, there is a large number of conventional banks that could be used to compare bank riskiness and financial crisis performance. Using all other banks as a control group is not feasible due to the small number of banks of interest. That is why I follow the matching literature and use pre-matching in the presence of a large and potentially heterogeneous control group (Imbens, 2014, Angrist and Pischke 2008). This pre-matching is implemented only to 
obtain an appropriate and less heterogeneous control group, not to obtain treatment effects that could be interpreted causally. Similar matching approaches are also used in the Islamic banking literature (Bourkhis and Nabi, 2013) and in the evaluation of socially responsible investment funds (Becchetti et al., 2014).

The matching process follows two steps. First, the total number of banks is reduced to banks that have similar characteristics as the alternative banks and are therefore good potential controls. Specifically, to serve as a potential control, the conventional bank must be active in the same country as the alternative bank and have balance sheet data available for a long enough time frame (2006-2009). Only banks enter that are of the same banking type as the alternative bank (commercial, savings and cooperative $)^{1}$. Banks that were part of large mergers are also dropped ${ }^{2}$. Banks must further be deposittaking, as all alternative banks are deposit taking. This leaves 3278 banks in the potential control group.

Second, the alternative banks are matched to conventional banks that closely resemble them using nearest neighbor matching. The banks are matched based on characteristics that are chosen to be important for the behavior and stability of the bank (e.g. bank size) and the business environment the bank acts in (e.g. country) but at the same time these characteristics should not be overly influenced by the status of the bank as being an alternative bank. Therefore, matching is done based on country of origin of the bank, bank size proxied by total assets, bank type (savings, cooperative or commercial) and the last year that the bank is observed in the dataset. The home country of the bank has effects on bank riskiness mainly through the macroeconomic environment but possibly also through national ideosyncracies in accounting standards or banking supervision. Bank size is linked to bank capitalization and riskiness in multiple ways. Larger banks often have more sophisticated risk management techniques that allow them to keep

1 There exists also one alternative building society in the UK which is classified as a "Real Estate and Mortgage bank" in Bankscope and matched with other UK building societies.

2 As Bankscope data does not contain information on mergers, merger control has to be somewhat approximate as in the related literature. Duprey and Lé (2014) recommend a cutoff of $50 \%$ of total assets growth but some small alternative banks experienced higher self-sustained growth than that in the first years after being founded. I follow Demirgüç-Kunt et al. (2006) and exclude banks whose total assets growth is outside a range of four standard deviations of total assets growth. As some of the alternative banks were also involved in mergers, this technique excludes only large mergers and data errors. 
lower capital ratios. Also, large banks may be more directly affected by turmoil on international financial markets. Smaller banks are typically less diversified and do not usually refinance themselves on the interbank market and therefore keep higher capital buffers (Jokipii and Milne, 2011). Bank type has also been linked with bank riskiness. For example, cooperative banks are found to be more stable than commercial banks (Hesse and Čihak, 2007).

To preserve the panel structure of the data, banks are matched in one specific year rather than matching each alternative bank with different banks each year. Banks are matched in the year 2006 in order of them to be unaffected by the outbreak of the financial crisis in summer 2007. Following a suggestion by Abadie et al. (2004), each bank is matched with four conventional controls. Using four controls yielded good mean-squared errors in simulations (Abadie and Imbens, 2002). See the appendix for a detailed technical description of the matching process and a discussion of multiple robustness checks of the matching methodology.

\subsection{Bank risk measures and control variables}

Bank risk measures

The main bank risk measure is the $\mathrm{z}$-score. It is defined as the fraction of the return on assets (ROA) plus the capital asset ratio (CAR) of the bank divided by its standard deviation of the return on assets.

$$
z \text {-score }{ }_{i, t}=\frac{R O A_{i, t}+C A R_{i, t}}{S D R O A_{i}}=\frac{\frac{\text { Net Income }_{i, t}}{\text { Assets }_{i, t}}+\frac{\text { Equity }_{i, t}}{\text { Assets }_{i, t}}}{s d\left(\frac{\text { Net Income }}{\text { Assets }}\right)_{i}}
$$

I calculate the standard deviation over all years that the bank is present in the sample. The z-score states how many standard deviations the banks' return on assets can decline until the bank becomes insolvent. When the returns of the bank are normally distributed the z-score is the inverse of the probability of insolvency of the bank (Beck et al., 2009). A higher z-score therefore means greater bank stability. The z-score is well-established in the empirical banking literature (see e.g. Boyd and Runkle 1993; 
Laeven and Levine 2009) and has been used in similar studies analyzing the Islamic banking sector (Čihak and Hesse, 2010).

The two time-varying components of the z-score, ROA and CAR are affected differently by the financial crisis. First, the return on assets should decrease in times of crisis. This effect may be even stronger for alternative banks as they experienced a high inflow of assets. In a low interest-rate environment this increase in deposits would not generate the same returns as the old deposits. Second, the capital asset ratio may fall in the financial crisis if the bank experiences losses that reduce capital. In case of the alternative banks, it might also fall due to an inflow in deposits.

Although the z-score is a very widely used measure of banking stability, it can be quite high if the bank has very stable earnings over time. This leads to a very low volatility in ROA and therefore to a very high z-score. As this may happen in the sample studied here and due to the effect of deposit inflows on the z-score, I consider several alternative risk measures. First, I follow Čihak and Hesse (2010) and implement two modified zscores that are based on downward volatility of return on assets rather than the overall volatility of return on assets. From a bank stability perspective, only downward spikes in return on assets are relevant. In the first modified z-score, downward volatility is proxied by the absolute value of the average negative deviations of the bank-specific ROA from its mean. In the second modified z-score, the downward volatility is proxied by the squared negative deviations of the bank-specific ROA from its mean (Hesse and Čihak, 2007). Lastly, I use the Regulatory Capital Ratio of banks, which is defined as the banks' total regulatory capital over its risk-weighted assets. While regular capital ratios are lowered by a strong inflow of deposits, which increases total assets without immediately increasing capital, the risk-weighted ratios are less affected by this.

Due to the relatively small size of all alternative banks, stock-market based risk measures cannot be employed. Information on non-performing loans (NPLs) is available for only about one-fifth of the banks sampled, which makes it unsuitable as a risk measure. Also, risk measures based on NPLs are often unreliable if troubled banks extend further credit to troubled creditors to avoid write-offs. Another possible venue of analysis of banking risk would be a comparison of bank failure rates via probit models or similar 
methods. However, due to very low numbers of observations this has to be left to future research.

\section{Bank control variables}

The regression equation includes an array of bank control variables. Many of them are adopted from the literature on riskiness of Islamic banks (see e.g. Čihak and Hesse, 2010) or have been found significant in explaining differences in bank riskiness. First, bank size is proxied by log total assets. Second, the banks' loans to assets ratio is included a measure of the banks balance sheet composition and its focus on traditional lending business. In some specifications the loan to deposit ratio is also included. It indicates how well the bank is able to transform deposits into interest-bearing loans. Third, the cost to income ratio is a measure of efficiency of the bank. Less efficient banks will generate lower returns and may also be worse at risk management. However, it may be not a meaningful efficiency measure for alternative banks that do not aim to generate income from their business. Fourth, the income diversity measure introduced by Laeven and Levine (2007) is an indicator on how much the bank generates its income

via granting of loans rather than other activities. This measure is also used by Čihak and Hesse (2010). A bank with diverse income sources can be more stable in times of low interest rates but it can also indicate that the bank is not focussing on traditional banking business. A high share of non-interest income has been linked with higher stability in German retail-oriented banks (Köhler, 2014). Lastly, the ratio of customer deposits to total assets is another indicator of traditional banking activity. Less reliance on wholesale deposit funding and the interbank market can be protective in crises and shows that the bank is closely connected to its community.

\subsection{Descriptive statistics of the matched dataset}

This section offers an overview of alternative banks and describes the matched dataset, which is used in the later regression analysis. Among the 34 alternative banks are 13 commercial banks, 15 cooperative banks, five savings banks and one building society. 
These alternative banks are headquartered in 12 different EU and OECD countries ${ }^{1}$. The average size of an alternative bank is 4474 Million USD (Table 1). With a median size of 1763 Million USD, the size distribution is quite skewed. Table 2 provides summary statistics for the matched sample. It also compares the averages of the matched banks and the alternative banks and reports results from a significance test of sample means. Alternative banks are matched on size with conventional banks in the year 2006. Due to their higher rates of growth after 2006 they are on average slightly larger than conventional banks. Alternative banks have significantly lower loans to asset ratios (45\% versus $57 \%$ ) and loan deposit ratios than conventional banks ( $54 \%$ versus $71 \%$ ). This confirms findings by Scheire and De Maertelaere (2009). These lower loan ratios may indicate that alternative banks have difficulties in finding enough viable borrowers but can also indicate that the banks prefer to keep larger liquidity buffers. The cost to income ratio is ususally a measure of bank efficiency. The significantly higher cost to income ratio of alternative banks could therefore indicate that alternative banks are less efficient, but it could also be due to the fact that not all alternative banks are income-maximizing. The income diversity indicator shows that alternative banks have significantly less diverse income sources than conventional banks. This is probably due to their focus on core banking activities.

The ratio of customer deposits to total assets is significantly higher in alternative banks $(77 \%)$ than in conventional banks $(65 \%)$. This is to be expected due to the focus of alternative banks on the real economy. Without controlling for any other variables, the average z-score of alternative banks is significantly higher than that of conventional banks. In this sample of banks, z-scores in general are rather high, because many banks are rather well capitalized (high CAR). Additionally, the return on assets is rather low for both the alternative banks and for the matched sample when compared to the return on assets of all banks including large commercial and investment banks. For the second risk measure, the regulatory capital ratio, there is no significant difference between banking groups.

Figure 1 in the appendix shows the amount of total assets of the alternative banks and

1 Austria, Belgium, Denmark, France, Germany, Great Britain, Italy, Malta, the Netherlands, Norway, Spain and Switzerland 
the matched conventional banks over time. Both banking groups experience increases in total assets over time, but since the outbreak of the financial crisis in 2007, the total assets of alternative banks have grown at a much higher rate than that of the matched conventional banks. This is in line with Benedikter (2011) who states that total assets of ethical banks in Europe doubled between 2007 and 2010. The slight decrease of average total assets in 2012 is due to the fact that two rather large alternative banks exit the sample in 2011. Due to concerns that the growth in total assets may be driven by mergers or by large banks I restrict the data to banks that are available in the dataset from 2002-2012 and not involved in large mergers since the outbreak of the crisis. Figure 2 confirms the higher growth of alternative banks using the median total assets of this restricted sample.

The amount of customer deposits held by alternative banks is also steadily increasing and higher than that of the control group (Figure 3). This stronger increase in customer deposits after the financial crisis is again robust when using the restricted dataset (Figure 4). When looking at the development of current customer deposits (Figures 5 and 6) the increased inflow of deposits since the outbreak of the financial crisis becomes even more apparent.

\section{Regressions and results}

\subsection{Riskiness of alternative banks}

The following regressions evaluate the riskiness of alternative banks in comparison with conventional banks.

$$
R I S K_{i, t}=\alpha+\beta_{1} \text { Alt. Bank } k_{i}+\beta_{2} B_{i, t}+\gamma \text { Country }_{j}+\delta \text { Year }_{t}+\epsilon_{i, t}
$$

The dependent variable is the bank risk of bank $i$ in year $t$. It is proxied by the z-score in the baseline specification. The effect of being an alternative bank (or not) is captured in the regression with the dummy variable "Alt. Bank" that equals one if the bank is 
an alternative bank and zero if it is a conventional bank. If the alternative banks had, for example, lower z-scores (were less stable) than the conventional banks, the dummy variable would have a negative coefficient sign in the regression. B is a vector of bank specific variables discussed in the previous section. It includes indicator variables of bank type (savings bank, cooperative or commercial bank), bank size proxied via log total assets, a measure of income diversity and the cost to income ratio as a measure of cost efficiency. It also includes the ratio of customer deposits to total assets and the ratio of loans to total assets, which has been shown to be significantly lower in alternative banks than in conventional banks (Table 2). Some specifications add the loan deposit ratio as a measure of conversion of deposits into loans. To account for country-specific characteristics and macroeconomic effects, the regression specification also includes country and year fixed effects. The inclusion of bank fixed effects is not possible as the status of being an alternative bank is also fixed over time. That is why the regression is implemented using pooled ordinary least squares (OLS) following Čihak and Hesse (2010).

Table 5 presents results for the baseline specification. In all specifications, the alternative bank status is associated with a significantly higher z-score and therefore greater stability. Larger banks and banks with a higher fraction of customer deposit funding are also more stable. Banks with more diverse income are less stable. As the cost to income ratio is insignificant in all regression specifications, it is not included in further regressions. Year fixed effects (columns 6 and 7) were found to be jointly insignificant and are also dropped.

\section{Robustness to different risk measures}

In Table 6 the regression is repeated using different specifications of the z-score. Column (1) includes a z-score calculated using the expected ROA, proxied by a moving average of the past 3 years rather than the current ROA, which leaves results virtually unchanged. From a perspective of financial stability only negative deviations from the average ROA are of interest (Čihak and Hesse, 2010). Columns (2) and (3) therefore report regression results using two z-scores based on downward volatility. Here, the alternative banks show even greater stability than conventional banks. This indicates that alternative 
banks are especially risk-averse. In column (4) the z-score is winsorized at the $1 \%$ and $99 \%$ level due to the concern that the regression results might be driven by outliers. Again, results are robust. However, the regression results using the regulatory capital ratio as a risk measure (columns 1 and 2 of Table 11) show no significant relationship between regulatory capital and alternative banking status. One caveat is that this alternative risk measure is only available for about one third of the banks in the sample.

\section{Robust regression methods}

Least squares regression methods are especially vulnerable to outliers due to the squared error term. In the case of alternative banking, the distribution of regression covariates is affected by some outliers. However, these are not data errors, rather this is due to the inherent heterogeneity of alternative banks. To ensure that the previous regression results do not depend on a few individual banks, I repeat the baseline regression using two different estimation techniques that are robust to outliers. Čihak and Hesse (2010) use the same robust regression techniques due to similar considerations for Islamic banks. Columns (1) and (2) in Table 7 present results using a weighted regression method that is robust to outliers. Specifically, the outlier-robust estimator described in Hamilton (2012) identifies outliers in an iterative procedure and assigns them lower weights in the regression. Columns (3) and (4) present results using a median least squares regression. In both specifications, the coefficient values of the alternative bank indicator are somewhat lower but still positive and highly significant.

As an additional robustness check, equation 2 is modified by lagging all bank-specific explanatory variables by one year. This should mitigate potential issues of endogeneity. The results in table 8 show that the main result as well as the coefficients of bankspecific variables are very robust to the inclusion of lagged bank specific variables. As lagging the bank-specific variables leaves the main results unchanged but further reduces a rather small dataset, lagged terms are only included as a robustness exercise.

\section{Inclusion of interaction terms}

The regression results could be biased due to the presence of the bank characteristics, if they too are influenced by alternative banking status. As some of the bank specific variables collected in the vector B may be directly influenced by the alternative banking 
status, the above regression equation is modified to a fully interacted model where each regressor is interacted with the alternative bank dummy. This follows Čihak and Hesse (2010) who also include interaction variables of bank characteristics with the bank type when the bank characteristic differs between bank types.

$$
R I S K_{i, t}=\alpha+\beta_{1} \text { Alt. Bank } k_{i}+\beta_{2} B_{i, t}+\beta_{3} \text { Alt.Bank } k_{i} * B_{i, t}+\gamma \text { Country }_{j}+\delta \text { Year }_{t}+\epsilon_{i, t}
$$

Results are presented in Table 9. While some of the interaction with bank characteristics are highly significant they leave the main result unchanged. The coefficient values of the alternative bank indicator remain very similar and highly significant. This indicates that the alternative bank indicator captures other stabilizing features of the banks that are not directly controlled for in the regression. These differences could be due to the different business culture of alternative banks, for example, a conservative loan portfolio, high-quality loan monitoring or a particularly dedicated staff.

\subsection{Stability of alternative banks in the global financial crisis}

The second area of research is the question if alternative banks were affected differently by the financial crisis. As the higher growth rates of alternative banks since the onset of the financial crisis have already been explored graphically in the previous section, this section focuses on the effect of the crisis on bank stability. This is evaluated by introducing a crisis indicator in the regression and interacting it with the alternative bank dummy. The use of a crisis dummy and the inclusion of interaction terms to capture crisis effects is typical in the literature (Beck et al., 2013). Two different crisis indicators are used, both based on GDP. As the alternative banks, as well as their matched counterparts, are comparatively small banks and few are active traders on financial markets, the financial crisis should most likely affect them via the real economy. The first measure, a crisis intensity measure, is the yearly loss of GDP, in percent, of the country where the bank is located. If the GDP grows, the crisis measure equals zero. This measure indicates the presence of a crisis for all countries in 2009 and for some 
countries in 2003, 2004, 2008, 2010 and 2012. The second crisis measure is a dummy that equals one if the home country of the bank experienced negative GDP growth that year.

$$
\begin{aligned}
\text { RISK }_{i, t}= & \alpha+\beta_{1} \text { Alt. Bank }_{i}+\beta_{2} B_{i, t}+\beta_{3} \text { Crisis }_{j, t} \\
& +\beta_{4} \text { Alt. Bank } k_{i} * \text { Crisis }_{j, t}+\gamma \text { Country }_{j}+\epsilon_{i, t}
\end{aligned}
$$

When using the z-score as a risk indicator I find no significant effect of the interaction term between the alternative bank dummy and the crisis indicator. The crisis indicator itself displays a negative, but not significant coefficient. In terms of z-score, there is no additional difference between alternative and conventional banks in times of crisis. This may be due to the multiple effects of the financial crisis on the z-scores of alternative banks discussed in section 2.3. Specifically, an inflow of deposits would c.p. increase total assets and therefore lower z-scores. That is why, in the following, a risk-weighted risk measure that should be less affected by capital inflows is used.

Table 11 presents results using the regulatory capital ratio as a risk measure. Both crisis indicators display negative coefficients, which indicates that banks lose in terms of regulatory capital in times of economic crisis. However, only the crisis intensity measure is significant. Interestingly, the alternative banking indicator is not significant when the regulatory capital ratio is used without including crisis measures (Columns 1 and 2). When crisis effects are included, it even becomes negative and significant. However, the interaction of both crisis measures with the alternative bank dummy is positive and significant in all specifications. This indicates that alternative banks proved more resilient in terms of regulatory capital in times of crisis than conventional banks. Due to the limited sample size for the regulatory capital ratio and the fact that no significant results are obtained using the z-score, results must be viewed as preliminary. When repeating these regressions using robust and quantile regression methods they loose significance. When interpreting the results it must not be forgotten that the control group consists of other small banks, many of them cooperative and savings banks, most of which were also not at the center of the financial crisis. The fast 
growth of alternative banks since the global financial crisis may obscure the pure crisis effects on the banks. While the final effect of the rapid growth of alternative banks remains to be seen, they were not less stable than the control group during the crisis.

\section{Conclusion}

This paper studies the riskiness of alternative banks in general and, specifically, during the financial crisis. This is the first study, I am aware of, to compile a comprehensive dataset of alternative banks and evaluate their riskiness compared to an adequate control group of conventional banks. The main result is that alternative banks, such as social and ethical banks, are significantly more stable than conventional banks. This result is confirmed using a wide array of robustness checks and is robust to different specifications of the main risk measure. The results are further confirmed using several robust regression methods. There is some evidence that in times of economic crisis alternative banks also prove more resilient in terms of regulatory capital than their conventional counterparts. The fast growth of alternative banks during and after the financial crisis makes bank risk measures based on total assets, such as the z-score, difficult to interpret. One avenue for further research is the analysis of alternative bank stability using risk measures that are less affected by bank growth.

When interpreting the results one must nevertheless keep in mind that the number of alternative banks used in the analysis is by necessity quite small. This is mostly due to the very small number of alternative banks in general and the limited number of years that they were included in Bankscope. It must also be noted that by using balance sheet-generated risk measures, all results necessarily suffer from some survivorship bias. Some alternative banks did fail during the financial crisis and/or had to merge after financial difficulties. This, of course, also holds for conventional banks. A separate analysis of bank failure probabilities could be an avenue for future research assuming that the sample size of bank failures increases over time.

As alternative banks hold only a tiny fraction of banking system assets in Europe, the direct effect of alternative banking on financial stability is accordingly small. However, 
by their sheer existence alternative banks show that different ways of conducting banking business are possible, which may influence how other market participants act in turn. Supporting this line of thought, Becchetti et al. (2013) develop a model where profit maximizing firms may find it optimal to adopt measures of corporate social responsibility when socially responsible, not profit maximizing, firms enter the market. Therefore, the fact that alternative banks do exist may be a positive influence the behavior of conventional banks.

As a final note, it must be added that this paper studies alternative banking from a view of stability. Positive effects on the social economy, the environment and the society in general cannot be quantified here but are nevertheless a central aspect of alternative banking. 


\section{A Appendix}

\section{A.1 Matching methodology and robustness}

\section{Matching methodology}

As alternative banks make up only a tiny fraction of the banking market, there is a large number of conventional banks that could be used to compare bank riskiness and financial crisis performance. Using all other banks as a control group is not feasible due to the small number of banks of interest. That is why I follow the matching literature and use pre-matching in the presence of a large and potentially heterogeneous control group (Imbens, 2014; Angrist and Pischke, 2008). Notably, this means that the pre-matching process should not be associated with the matching methods used for obtaining causal inference in the context of treatment evaluation (e.g. propensity score matching).

The alternative banks are matched to conventional banks that closely resemble them in basic characteristics using nearest neighbor matching. The banks are matched based on characteristics that are chosen to be important for the behavior and stability of the bank (e.g. bank size) and the business environment the bank acts in (e.g. country) but at the same time these characteristics should not be overly influenced by the status of the bank as being an alternative bank. Matching is done based on country, bank specialization (savings, cooperative or commercial), bank size and the last year the bank was available in Bankscope. The bank specialization is assigned by Bankscope based on the annual report of the bank. One alternative bank is, most likely erroneously, classified as a "finance company" in Bankscope and reclassified as a cooperative bank for the analysis. One British alternative building society is classified as a "Real Estate and Mortgage bank" in Bankscope and is matched with other British building societies. Bank size is proxied by total assets in 2006, that is, before the outbreak of the financial crisis. Of the banks that are available long enough for the regression analysis, three are not available until the end of the sample. One bank leaves the sample in 2009, two others in 2011. As one of the matching variables is the last year that the bank was observed in the dataset, these are matched with banks that left the dataset at a similar time. Both alternative banks and conventional banks in the matched dataset 
are observed in Bankscope for 12 or 13 years, on average.

The matching process is implemented using the Stata command nnmatch. The nearest neighbor matching minimizes the Mahalanobis distance between the covariates. The Mahalanobis distance is invariant to scale and accounts for correlation of the matching variables (see e.g. Härdle and Simar, 2012).

To specify, this means that matching is done directly on the covariates and not on, for example, the propensity score. In the context of this paper, the more direct method is preferred as matching is employed only as a pre-matching and not for causal inference and there are few and mostly categorical covariates used for matching. For country and bank type exact matching is specified. This means in practice that these variables enter the weighting matrix with their original weight multipied with 1000 (Abadie et al., 2004). Banks are matched with replacement which leads to higher quality matching than without replacement (Abadie and Imbens, 2002). Following a suggestion by Abadie et al. (2004), each alternative bank is matched with four conventional controls which yielded good mean-squared errors in simulations.

\section{Robustness of results to matching specifications}

This matched dataset is used for all regressions except in Table 10 which presents a series of robustness checks of matching specification and data choice. Column (1) presents results for only the 1997-2011 period. The year 2012 is omitted from the regression because two alternative banks left the sample in that year. Column (2) repeats the matching using a sample that controls for mergers and panel attrition. Both the alternative banking groups as well as the other banks were involved in mergers and acquisitions during the time studied. In the baseline specification, only banks involved in large mergers are dropped from the sample. In column (2) banks are excluded from the alternative and in the control group if they experienced a total assets growth of 50\% or more since 2006 (Duprey and Lé, 2014). Before 2006, banks are only subjected to the merger control following the baseline specification as some alternative banks experienced self-sustained growth greater than $50 \%$ just after founding. Bank mergers and acquisitions are one cause of sample attrition. Riskier banks could be more involved in take-overs, either as a receiving entity if they are more prepared to engage in 
potentially risky take-overs or as candidates for a takeover if past risk-taking destabilized their financial position. In order to control for possible effects of sample attrition, the dataset used in column (2) also includes only banks with data available from 2003 through 2012 or longer. Column (3) does not use exact matching for country and bank type. While these are important variables in term of bank risk, the exact matching could lead to insufficient weight being placed on bank size. Columns (4) and (5) check whether the results are robust to the number of banks being matched and report results on 1:6 and 1:3 matching, respectively. Column (6) implements a bias adjustment that "adjusts the difference within the matches for the differences in their covariate values" (Abadie et al., 2004, p. 298). As this bias only occurs when more than one continuous variable is included in the matching or when the potential sample is too small, this bias adjustment is not included in the baseline specification (Abadie and Imbens, 2002). The matched dataset in column (7) uses the inverse variance weighting matrix instead of the Mahalanobis distance. Column (8) checks whether the result is robust to the ordering of the matched variables. In the presence of categorical variables, the ordering of the variables in the matching process can affect the outcome of the match. Here, all matching variables, except the bank size, are categorical. That is why column (8) presents results from a different ordering of the matched variables. Lastly, the dataset used in column (9) matches the banks in 2007 instead of 2006. While the turmoil on the US housing markets began in summer 2007, the height of the crisis was reached only in summer 2008 with the collapse of Lehman Brothers. Therefore, alternative banks may have been still unaffected by the crisis in 2007 and this year could also be used to match the banks. For all different data sets and robustness tests collected in Table 10 the coefficient values remain of similar size and significant. Results therefore do not depend on the exact construction of the dataset. 


\section{A.2 Data description and summary statistics}

Table 1: Summary statistics for alternative banks

\begin{tabular}{lccccc}
\hline & Number & Mean & Standard deviation & Minimum & Maximum \\
\hline Total Assets (Mill. USD) & 381 & 4,474 & 9,867 & 21 & 78,229 \\
Loans / Assets & 381 & 45.20 & 21.69 & 1.72 & 89.05 \\
Cost / Income & 361 & 26.64 & 39.65 & 2.07 & 301.43 \\
Income diversity & 381 & 22.05 & 15.46 & 0.00 & 92.72 \\
Customer deposits / Assets & 381 & 76.80 & 15.37 & 10.23 & 96.73 \\
Loan deposits ratio & 381 & 53.84 & 28.88 & 1.80 & 140.16 \\
z-score & 381 & 88.73 & 135.82 & 1.89 & 983.70 \\
z-score (expected ROA) & 324 & 89.14 & 141.52 & 1.41 & 983.86 \\
Downward z-score (I) & 381 & 125.24 & 192.76 & 2.01 & $1,211.24$ \\
Downward z-score (II) & 381 & 106.74 & 163.08 & 1.69 & $1,040.20$ \\
Regulatory Capital Ratio & 147 & 16.84 & 6.12 & 9.50 & 69.10 \\
\hline
\end{tabular}




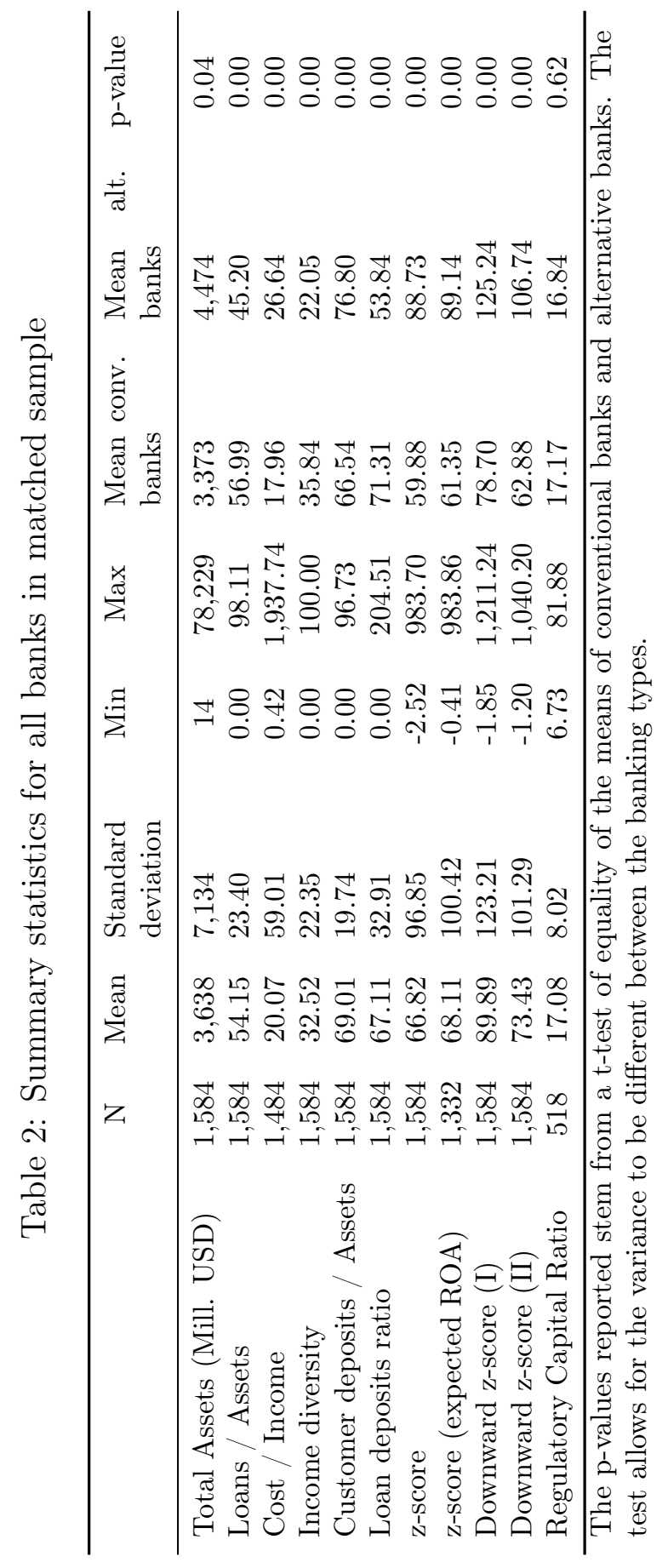


Table 3: Variable overview and definitions

\begin{tabular}{|c|c|c|}
\hline Variable & Description / Calculation & Source \\
\hline \multicolumn{3}{|c|}{ Risk measures and components thereof } \\
\hline Z-score & $=\frac{R O A_{i, t}+C A R_{i, t}}{S D R O A_{i}}$ & $\begin{array}{l}\text { calculation based on Bankscope } \\
\text { data }\end{array}$ \\
\hline $\begin{array}{l}\text { z-score (Expected } \\
\text { ROA) }\end{array}$ & $=\frac{\frac{1}{3} *\left(R O A_{i, t}+R O A_{i, t-1} R O A_{i, t-2}\right)+C A R_{i, t}}{S D R O A_{i}}$ & $\begin{array}{l}\text { calculation based on Bankscope } \\
\text { data }\end{array}$ \\
\hline $\begin{array}{l}\text { Downward z-score } \\
\text { (I) }\end{array}$ & $\begin{array}{l}\text { as standard z-score, but with downward abso- } \\
\text { lute volatility of return on assets }\end{array}$ & $\begin{array}{l}\text { calculation based on Bankscope } \\
\text { data, specification following } \\
\text { Hesse and Čihak (2007) }\end{array}$ \\
\hline $\begin{array}{l}\text { Downward z-score } \\
\text { (II) }\end{array}$ & $\begin{array}{l}\text { as standard z-score, but with downward } \\
\text { squared volatility of return on assets }\end{array}$ & $\begin{array}{l}\text { calculation based on Bankscope } \\
\text { data, specification following } \\
\text { Hesse and Čihak (2007) }\end{array}$ \\
\hline $\begin{array}{l}\text { Return on Assets } \\
\text { (ROA) }\end{array}$ & Net income / Total assets & $\begin{array}{l}\text { calculation based on Bankscope } \\
\text { data }\end{array}$ \\
\hline $\begin{array}{l}\text { Capital Asset Ratio } \\
(\mathrm{CAR})\end{array}$ & Total equity / Total assets & $\begin{array}{l}\text { calculation based on Bankscope } \\
\text { data }\end{array}$ \\
\hline $\begin{array}{l}\text { Regulatory Capital } \\
\text { Ratio }\end{array}$ & Total regulatory capital ratio $(\%)$ & Bankscope \\
\hline \multicolumn{3}{|l|}{ Control variables } \\
\hline $\begin{array}{l}\text { Alternative bank } \\
\text { indicator }\end{array}$ & $\begin{array}{l}1 \text { for alternative banks, } 0 \text { for conventional } \\
\text { banks }\end{array}$ & own research \\
\hline $\begin{array}{l}\text { Bank type indica- } \\
\text { tor }\end{array}$ & $\begin{array}{l}\text { indicator variables for conventional, coopera- } \\
\text { tive and savings banks }\end{array}$ & Bankscope \\
\hline Bank size & $\log ($ total assets $)$ & $\begin{array}{l}\text { calculation based on Bankscope } \\
\text { data }\end{array}$ \\
\hline Income diversity & $=1-\left|\frac{\text { Net interest income-other operating income }}{\text { Total Operating Income }}\right|$ & $\begin{array}{l}\text { calculation based on Bankscope } \\
\text { data, specification following } \\
\text { Laeven and Levine (2007) }\end{array}$ \\
\hline Loans / Assets & Net loans / Total assets & $\begin{array}{l}\text { calculation based on Bankscope } \\
\text { data }\end{array}$ \\
\hline $\begin{array}{l}\text { Cost to income ra- } \\
\text { tio }\end{array}$ & $\begin{array}{l}\text { (Interest }+ \text { Non-interest expense)/ Net in- } \\
\text { come }\end{array}$ & $\begin{array}{l}\text { calculation based on Bankscope } \\
\text { data }\end{array}$ \\
\hline $\begin{array}{l}\text { Customer Deposits } \\
/ \text { Assets }\end{array}$ & Customer deposits / Total assets & $\begin{array}{l}\text { calculation based on Bankscope } \\
\text { data }\end{array}$ \\
\hline Loan deposit ratio & $\begin{array}{l}\text { Net loans / (Total deposits, money market } \\
\text { and short term funding) }\end{array}$ & $\begin{array}{l}\text { calculation based on Bankscope } \\
\text { data }\end{array}$ \\
\hline GDP growth & percentage change yearly, current prices & Eurostat \\
\hline
\end{tabular}

To allow for correct interpretation, ratios relying on income data in numerator and denominator are set missing if the banks' income is negative. 
Table 4: Correlation table of bank control variables

\begin{tabular}{|c|c|c|c|c|c|c|}
\hline & Bank size & $\begin{array}{l}\text { Loans/ } \\
\text { Assets }\end{array}$ & $\begin{array}{l}\text { Customer } \\
\text { deposits/ } \\
\text { Assets }\end{array}$ & $\begin{array}{l}\text { Income } \\
\text { diversity }\end{array}$ & $\begin{array}{l}\text { Cost/ } \\
\text { Income }\end{array}$ & $\begin{array}{l}\text { Loan de- } \\
\text { posit ratio }\end{array}$ \\
\hline Bank size & 1 & & & & & \\
\hline Loans / Assets & 0.0741 & 1 & & & & \\
\hline $\begin{array}{l}\text { Customer deposits } \\
\text { / Assets }\end{array}$ & -0.148 & -0.0592 & 1 & & & \\
\hline Income diversity & 0.0617 & -0.288 & -0.390 & 1 & & \\
\hline Cost / income & 0.0472 & -0.0715 & 0.0436 & 0.0157 & 1 & \\
\hline Loan deposit ratio & 0.0983 & 0.923 & -0.240 & -0.163 & -0.0841 & 1 \\
\hline
\end{tabular}




\section{A.3 Figures}

Figure 1: Total assets of alternative and conventional banks

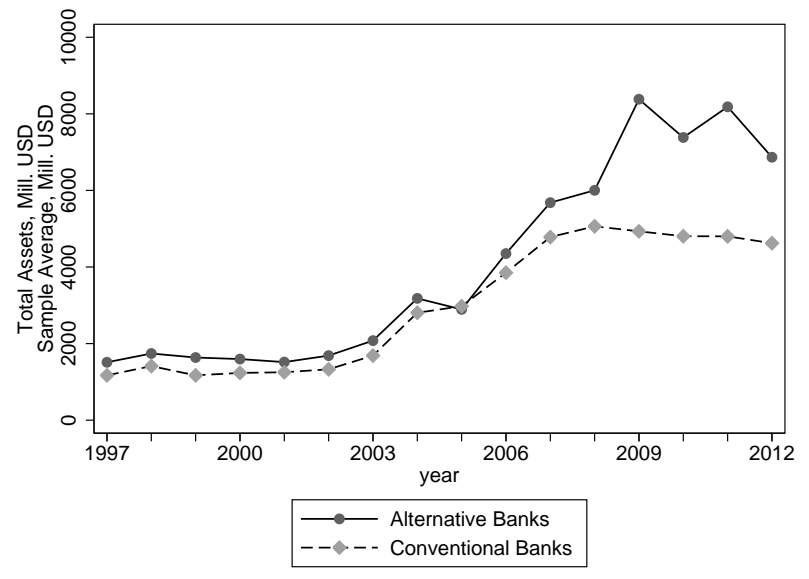

Figure 2: Total assets of alternative and conventional banks

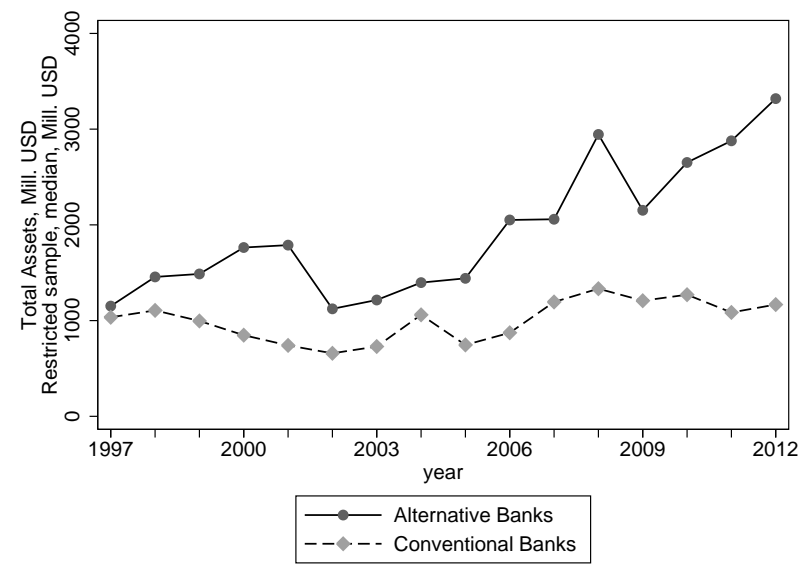

This figure reports the total assets of alternative and conventional banks in an outlier -robust modification of above figure. It reports the median total assets of a dataset that is restricted to banks that are available in the dataset from 2002-2012 and not involved in large mergers since the outbreak of the crisis. 
Figure 3: Customer deposits of alternative and conventional banks

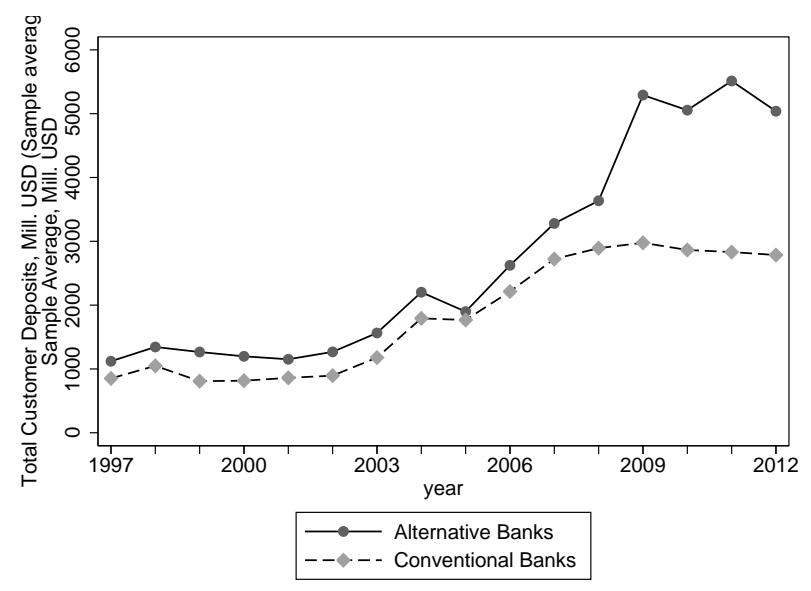

Figure 4: Customer deposits of alternative and conventional banks

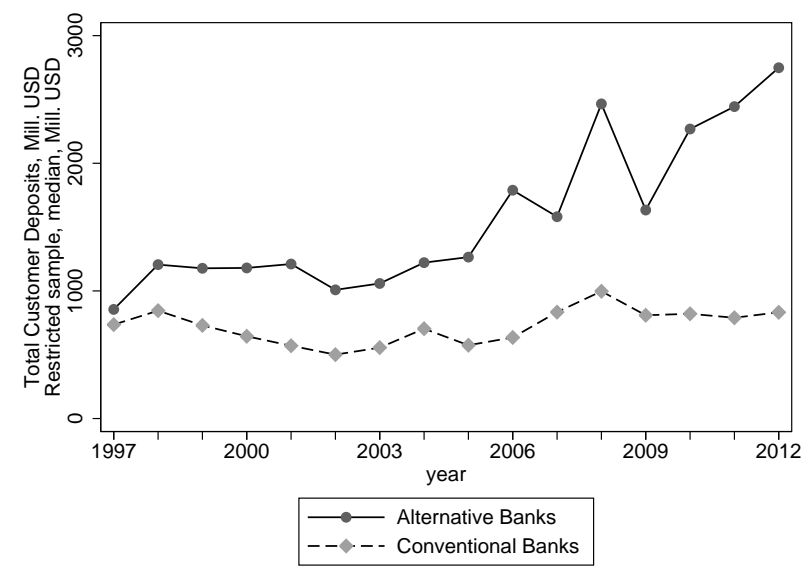

This figure reports the customer deposits of alternative and conventional banks in an outlier -robust modification of above figure. It reports the median total assets of a dataset that is restricted to banks that are available in the dataset from 2002-2012 and not involved in large mergers since the outbreak of the crisis. 
Figure 5: Current customer deposits of alternative and conventional banks

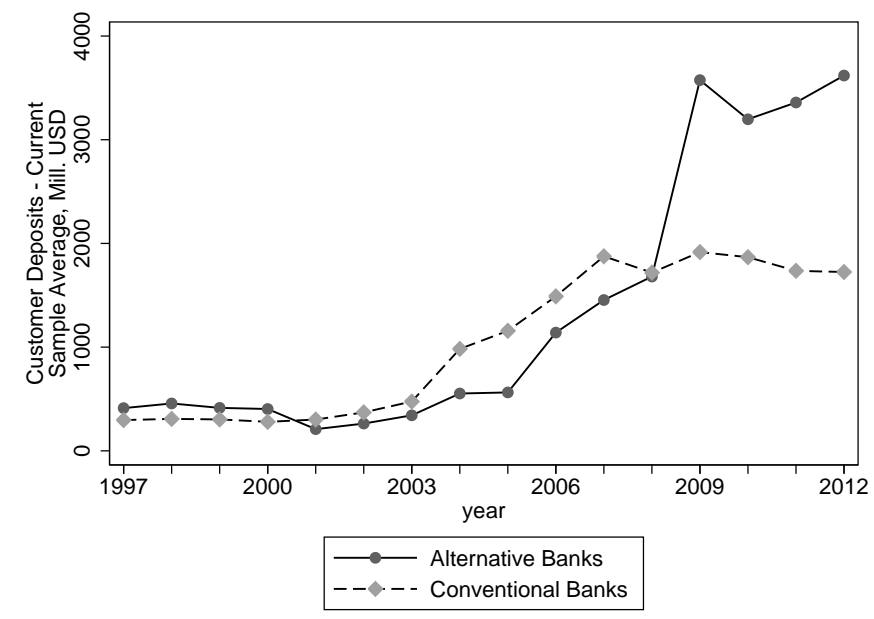

Figure 6: Current customer deposits of alternative and conventional banks

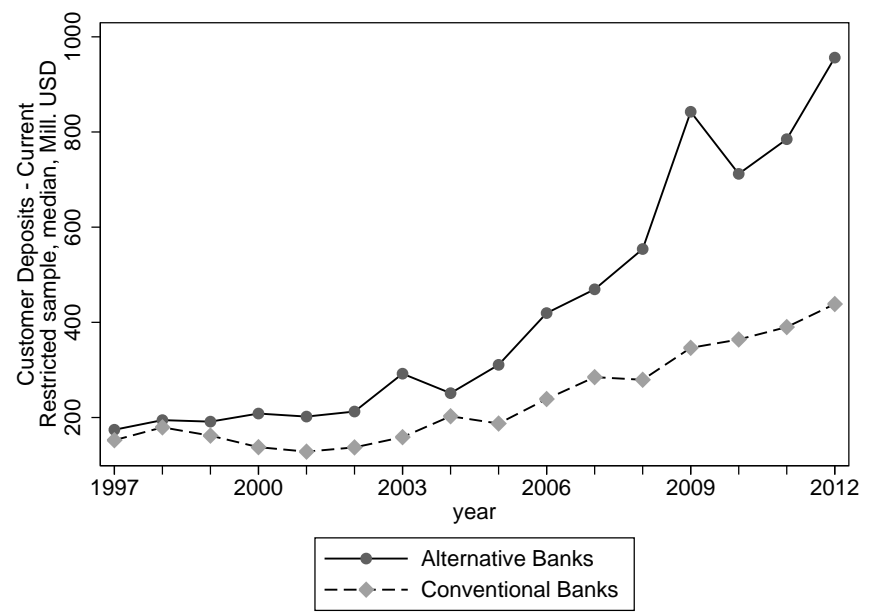

This figure reports the current customer deposits of alternative and conventional banks in an outlier -robust modification of above figure. It reports the median customer deposits of a dataset that is restricted to banks that are available in the dataset from 2002-2012 and not involved in large mergers since the outbreak of the crisis. 


\section{A.4 Regression results}

Table 5: Regression results - Comparing the riskiness of conventional and alternative banks

\begin{tabular}{lccccccc}
\hline & $(1)$ & $(2)$ & $(3)$ & $(4)$ & $(5)$ & $(6)$ & $(7)$ \\
\hline Alternative bank dummy & $14.72^{* *}$ & $10.79^{*}$ & $14.51^{* *}$ & $18.49^{* * *}$ & $17.82^{* * *}$ & $14.78^{* *}$ & $14.56^{* *}$ \\
& {$[6.06]$} & {$[6.19]$} & {$[6.06]$} & {$[5.89]$} & {$[5.96]$} & {$[6.07]$} & {$[6.07]$} \\
Bank size & $6.44^{* * *}$ & $8.08^{* * *}$ & $6.16^{* * *}$ & $5.95^{* * *}$ & $5.79^{* * *}$ & $5.79^{* * *}$ & $5.42^{* * *}$ \\
& {$[1.62]$} & {$[1.75]$} & {$[1.63]$} & {$[1.36]$} & {$[1.37]$} & {$[1.54]$} & {$[1.55]$} \\
Loans / Assets & $0.33^{* * *}$ & $0.26^{* *}$ & -0.12 & $0.49^{* * *}$ & -0.10 & $0.33^{* * *}$ & -0.16 \\
& {$[0.09]$} & {$[0.11]$} & {$[0.20]$} & {$[0.09]$} & {$[0.19]$} & {$[0.09]$} & {$[0.20]$} \\
Customer deposits / Assets & $0.44^{* * *}$ & $0.57^{* * *}$ & $0.54^{* * *}$ & $0.45^{* * *}$ & $0.56^{* * *}$ & $0.43^{* * *}$ & $0.53^{* * *}$ \\
& {$[0.11]$} & {$[0.14]$} & {$[0.11]$} & {$[0.09]$} & {$[0.09]$} & {$[0.11]$} & {$[0.11]$} \\
Income diversity & $-0.77^{* * *}$ & $-0.72^{* * *}$ & $-0.78^{* * *}$ & $-0.73^{* * *}$ & $-0.75 * * *$ & $-0.80^{* * *}$ & $-0.81^{* * *}$ \\
& {$[0.12]$} & {$[0.12]$} & {$[0.12]$} & {$[0.11]$} & {$[0.11]$} & {$[0.11]$} & {$[0.11]$} \\
Cost / Income & & -0.00 & & & & & \\
& & {$[0.03]$} & & & & & \\
Loan deposit ratio & & & $0.37^{* *}$ & & $0.45^{* * *}$ & & $0.40^{* * *}$ \\
& & & {$[0.15]$} & & {$[0.15]$} & & {$[0.15]$} \\
Constant & -22.91 & $-39.26^{* *}$ & $-26.99^{*}$ & 0.71 & -4.46 & -20.48 & -25.01 \\
& {$[14.41]$} & {$[16.92]$} & {$[14.27]$} & {$[11.08]$} & {$[10.83]$} & {$[17.32]$} & {$[17.15]$} \\
Bank type dummies & YES & YES & YES & YES & YES & YES & YES \\
Country dummies & YES & YES & YES & NO & NO & YES & YES \\
Year dummies & NO & NO & NO & NO & NO & YES & YES \\
\hline Observations & 1,584 & 1,484 & 1,584 & 1,584 & 1,584 & 1,584 & 1,584 \\
R-squared & 0.16 & 0.15 & 0.16 & 0.12 & 0.12 & 0.16 & 0.16 \\
\hline
\end{tabular}

This table reports the OLS regression estimates of equation 2. The dependent variable is the $\mathrm{z}^{-}$ score. Robust standard errors are in brackets. The p-values are as follows: ${ }^{* * *} \mathrm{p}<0.01,{ }^{* *} \mathrm{p}<0.05$, $* \mathrm{p}<0.1$ 
Table 6: Regression results. Robustness of calculation of z-score and modified z-scores

\begin{tabular}{lcccc}
\hline & $(1)$ & $(2)$ & $(3)$ & $(4)$ \\
z-score type & expected ROA & Downward I (Abs.) & Downward. II (Squrd.) & winsor \\
\hline Alternative bank dummy & $12.79^{*}$ & $30.00^{* * *}$ & $29.66^{* * *}$ & $10.40^{* *}$ \\
& {$[6.83]$} & {$[8.87]$} & {$[7.32]$} & {$[5.01]$} \\
Bank size & $7.62^{* * *}$ & $8.01^{* * *}$ & $6.62^{* * *}$ & $4.85^{* * *}$ \\
& {$[1.84]$} & {$[2.04]$} & {$[1.70]$} & {$[1.29]$} \\
Loans / Assets & $0.31^{* * *}$ & $0.54^{* * *}$ & $0.36^{* * *}$ & $0.38^{* * *}$ \\
& {$[0.10]$} & {$[0.12]$} & {$[0.10]$} & {$[0.08]$} \\
Customer dep. / Assets & $0.47^{* * *}$ & $0.69^{* * *}$ & $0.58^{* * *}$ & $0.36^{* * *}$ \\
& {$[0.12]$} & {$[0.13]$} & {$[0.11]$} & {$[0.09]$} \\
Income diversity & $-0.83^{* * *}$ & $-0.86^{* * *}$ & $-0.69^{* * *}$ & $-0.71^{* * *}$ \\
& {$[0.13]$} & {$[0.14]$} & {$[0.12]$} & {$[0.09]$} \\
Constant & $-27.32^{*}$ & $-47.31^{* * *}$ & $-36.81^{* *}$ & -12.64 \\
& {$[16.39]$} & {$[18.29]$} & {$[15.24]$} & {$[11.80]$} \\
Bank type dummies & YES & YES & YES & YES \\
Country dummies & YES & YES & YES & YES \\
\hline Observations & 1,332 & 1,584 & 1,584 & 1,584 \\
R-squared & 0.16 & 0.19 & 0.19 & 0.18 \\
\hline
\end{tabular}

This table reports the OLS regression estimates of equation 2. The dependent variable are different specifications of z-score as detailed in the header. Column (1) uses the expected ROA in the calculation of the z-score. Columns (2) and (3) use on downward volatility measures rather than overall volatility measures in the calculation of the z-score. Column (2) uses the absolute downward deviations and column (3) the squared downward deviations of the ROA, following Hesse and Cihak (2007). Column (4) reports results using a z-score that is winsorized at the $1 \%$ and $99 \%$ level. Robust standard errors are in brackets. The p-values are as follows: ${ }^{* * *} \mathrm{p}<0.01,{ }^{* *} \mathrm{p}<0.05, *$ $\mathrm{p}<0.1$ 
Table 7: Regression results. Use of robust and quantile regression methods.

\begin{tabular}{lcccc}
\hline & $(1)$ & $(2)$ & $(3)$ & $(4)$ \\
Regression method & robust & robust & $\begin{array}{c}\text { median } \\
\text { median }\end{array}$ \\
\hline Alternative bank dummy & $3.38^{*}$ & $5.74^{* * *}$ & $6.97^{* * *}$ & $8.93^{* * *}$ \\
& {$[2.02]$} & {$[2.16]$} & {$[2.59]$} & {$[3.18]$} \\
Bank size & -0.81 & 0.17 & $-1.25^{*}$ & -0.81 \\
& {$[0.58]$} & {$[0.54]$} & {$[0.74]$} & {$[0.80]$} \\
Loans / Assets & $0.35^{* * *}$ & $0.44^{* * *}$ & $0.45^{* * *}$ & $0.43^{* * *}$ \\
& {$[0.04]$} & {$[0.04]$} & {$[0.06]$} & {$[0.06]$} \\
Customer deposits / Assets & -0.06 & -0.05 & -0.06 & -0.03 \\
& {$[0.05]$} & {$[0.05]$} & {$[0.06]$} & {$[0.07]$} \\
Income diversity & $-0.40^{* * *}$ & $-0.31^{* * *}$ & $-0.33^{* * *}$ & $-0.29 * * *$ \\
& {$[0.04]$} & {$[0.05]$} & {$[0.06]$} & {$[0.07]$} \\
Constant & $35.38^{* * *}$ & $32.61^{* * *}$ & $31.46^{* * *}$ & $33.11^{* * *}$ \\
Bank type dummies & {$[7.00]$} & {$[6.44]$} & {$[8.98]$} & {$[9.47]$} \\
Country dummies & YES & YES & YES & YES \\
\hline Observations & YES & NO & YES & NO \\
R-squared & 1,584 & 1,584 & 1,584 & 1,584 \\
\hline
\end{tabular}

This table reports regression estimates of equation 2 using robust and quantile regression methods. The dependent variable is the z-score. Columns (1) and (2) report results using a estimation techniques robust to outliers in the data (see Hamilton, 2012 for a description). Columns (3) and (4) report median least squares regressions. Standard errors in brackets. The $\mathrm{p}$-values are as follows: ${ }^{* * *} \mathrm{p}<0.01,{ }^{* *} \mathrm{p}<0.05,{ }^{*} \mathrm{p}<0.1$ 
Table 8: Regression results - Bank-specific variables lagged by one year

\begin{tabular}{lccccccc}
\hline & $(1)$ & $(2)$ & $(3)$ & $(4)$ & $(5)$ & $(6)$ & $(7)$ \\
\hline Alternative bank dummy & $13.92^{* *}$ & 10.41 & $13.70^{* *}$ & $17.67^{* * *}$ & $16.87^{* * *}$ & $13.90^{* *}$ & $13.66^{* *}$ \\
& {$[6.46]$} & {$[6.58]$} & {$[6.47]$} & {$[6.22]$} & {$[6.31]$} & {$[6.47]$} & {$[6.48]$} \\
L. Bank size & $7.35^{* * *}$ & $8.74^{* * *}$ & $7.08^{* * *}$ & $6.63^{* * *}$ & $6.50^{* * *}$ & $6.69^{* * *}$ & $6.29^{* * *}$ \\
& {$[1.73]$} & {$[1.88]$} & {$[1.74]$} & {$[1.46]$} & {$[1.47]$} & {$[1.65]$} & {$[1.65]$} \\
L.Loans / Assets & $0.31^{* * *}$ & $0.24^{* *}$ & -0.17 & $0.47^{* * *}$ & -0.17 & $0.31^{* * *}$ & -0.22 \\
& {$[0.10]$} & {$[0.11]$} & {$[0.22]$} & {$[0.09]$} & {$[0.22]$} & {$[0.10]$} & {$[0.23]$} \\
L.Customer dep. / Assets & $0.46^{* * *}$ & $0.59^{* * *}$ & $0.55^{* * *}$ & $0.45^{* * *}$ & $0.57^{* * *}$ & $0.45^{* * *}$ & $0.55^{* * *}$ \\
& {$[0.12]$} & {$[0.15]$} & {$[0.12]$} & {$[0.10]$} & {$[0.10]$} & {$[0.12]$} & {$[0.12]$} \\
L.Income diversity & $-0.79^{* * *}$ & $-0.73^{* * *}$ & $-0.81^{* * *}$ & $-0.77^{* * *}$ & $-0.79^{* * *}$ & $-0.82^{* * *}$ & $-0.84^{* * *}$ \\
& {$[0.12]$} & {$[0.12]$} & {$[0.12]$} & {$[0.11]$} & {$[0.11]$} & {$[0.12]$} & {$[0.12]$} \\
L.Cost / Income & & 0.00 & & & & & \\
& & {$[0.04]$} & & & & & \\
L.Loan deposit ratio & & & $0.39^{* *}$ & & $0.49^{* * *}$ & & $0.44^{* *}$ \\
& & & {$[0.17]$} & & {$[0.17]$} & & {$[0.17]$} \\
Constant & $-27.77^{*}$ & $-43.46^{* *}$ & $-31.78^{* *}$ & -0.36 & -5.55 & -26.82 & $-31.39^{*}$ \\
& {$[15.61]$} & {$[18.46]$} & {$[15.53]$} & {$[11.75]$} & {$[11.47]$} & {$[18.09]$} & {$[18.10]$} \\
Bank type dummies & YES & YES & YES & YES & YES & YES & YES \\
Country dummies & YES & YES & YES & NO & NO & YES & YES \\
Year dummies & NO & NO & NO & NO & NO & YES & YES \\
\hline Observations & 1,455 & 1,366 & 1,455 & 1,455 & 1,455 & 1,455 & 1,455 \\
R-squared & 0.16 & 0.15 & 0.16 & 0.12 & 0.12 & 0.16 & 0.16 \\
\hline
\end{tabular}

This table reports the OLS regression estimates of equation 2 which is modified by lagging all bank-specific explanatory variables by one year to mitigate potential isues of endogeneity. The dependent variable is the z-score. Robust standard errors are in brackets. The p-values are as follows: ${ }^{* * *} \mathrm{p}<0.01,{ }^{* *} \mathrm{p}<0.05,{ }^{*} \mathrm{p}<0.1$ 
Table 9: Regression results. Addition of interaction terms of alternative bank status and bank-level control variables.

\begin{tabular}{lcccc}
\hline & $(1)$ & $(2)$ & $(3)$ & $(4)$ \\
Regression method & OLS & OLS & robust & robust \\
\hline Alternative Bank Dummy & $13.89^{* *}$ & $9.92^{*}$ & $14.40^{* * *}$ & $14.74^{* * *}$ \\
& {$[5.76]$} & {$[5.71]$} & {$[2.21]$} & {$[2.24]$} \\
Bank size & $7.22^{* * *}$ & $4.87^{* * *}$ & $-1.03^{*}$ & $-1.22^{* *}$ \\
& {$[1.73]$} & {$[1.36]$} & {$[0.57]$} & {$[0.61]$} \\
Alt.*Bank size & & $11.76^{* *}$ & & 1.40 \\
& & {$[4.75]$} & & {$[1.07]$} \\
Loans / Assets & $0.27^{* * *}$ & $0.31^{* * *}$ & $0.22^{* * *}$ & $0.23^{* * *}$ \\
& {$[0.09]$} & {$[0.09]$} & {$[0.05]$} & {$[0.05]$} \\
Alt.*Loans / Assets & 0.24 & 0.21 & $0.50^{* * *}$ & $0.51^{* * *}$ \\
& {$[0.24]$} & {$[0.25]$} & {$[0.09]$} & {$[0.09]$} \\
Customer deposits / Assets & $0.25^{* * *}$ & $0.22^{* *}$ & -0.03 & -0.03 \\
& {$[0.09]$} & {$[0.09]$} & {$[0.05]$} & {$[0.05]$} \\
Alt.*Customer deposits / Assets & $1.87^{* * *}$ & $2.20^{* * *}$ & 0.21 & $0.26^{*}$ \\
& {$[0.42]$} & {$[0.51]$} & {$[0.14]$} & {$[0.14]$} \\
Income diversity & $-0.92^{* * *}$ & $-0.90^{* * *}$ & $-0.56^{* * *}$ & $-0.56^{* * *}$ \\
& {$[0.09]$} & {$[0.08]$} & {$[0.05]$} & {$[0.05]$} \\
Alt.*Income diversity & $1.37^{* * *}$ & $1.35^{* * *}$ & $1.02^{* * *}$ & $1.03^{* * *}$ \\
Constant & {$[0.49]$} & {$[0.48]$} & {$[0.12]$} & {$[0.12]$} \\
& $46.59^{* * *}$ & $46.80^{* * *}$ & $32.63^{* * *}$ & $32.64^{* * *}$ \\
Bank type dummies & {$[4.11]$} & {$[4.12]$} & {$[3.45]$} & {$[3.46]$} \\
Country dummies & YES & YES & YES & YES \\
\hline Observations & YES & YES & YES & YES \\
R-squared & 1,584 & 1,584 & 1,584 & 1,584 \\
& 0.17 & 0.18 & 0.40 & 0.40 \\
& & & & \\
& & & &
\end{tabular}

This table reports the regression estimates of equation 3 using OLS (columns 1 and 2) and robust regression methods (columns 3 and 4). The dependent variable is the z-score. Robust standard errors are in brackets for OLS regressions. Standard errors are in brackets for robust regressions. The p-values are as follows: ${ }^{* * *} \mathrm{p}<0.01,{ }^{* *} \mathrm{p}<0.05,^{*} \mathrm{p}<0.1$ All bank control and interacted variables are demeaned for ease of interpretation (See Balli and Sørensen, 2013; Brambor et al., 2006). 


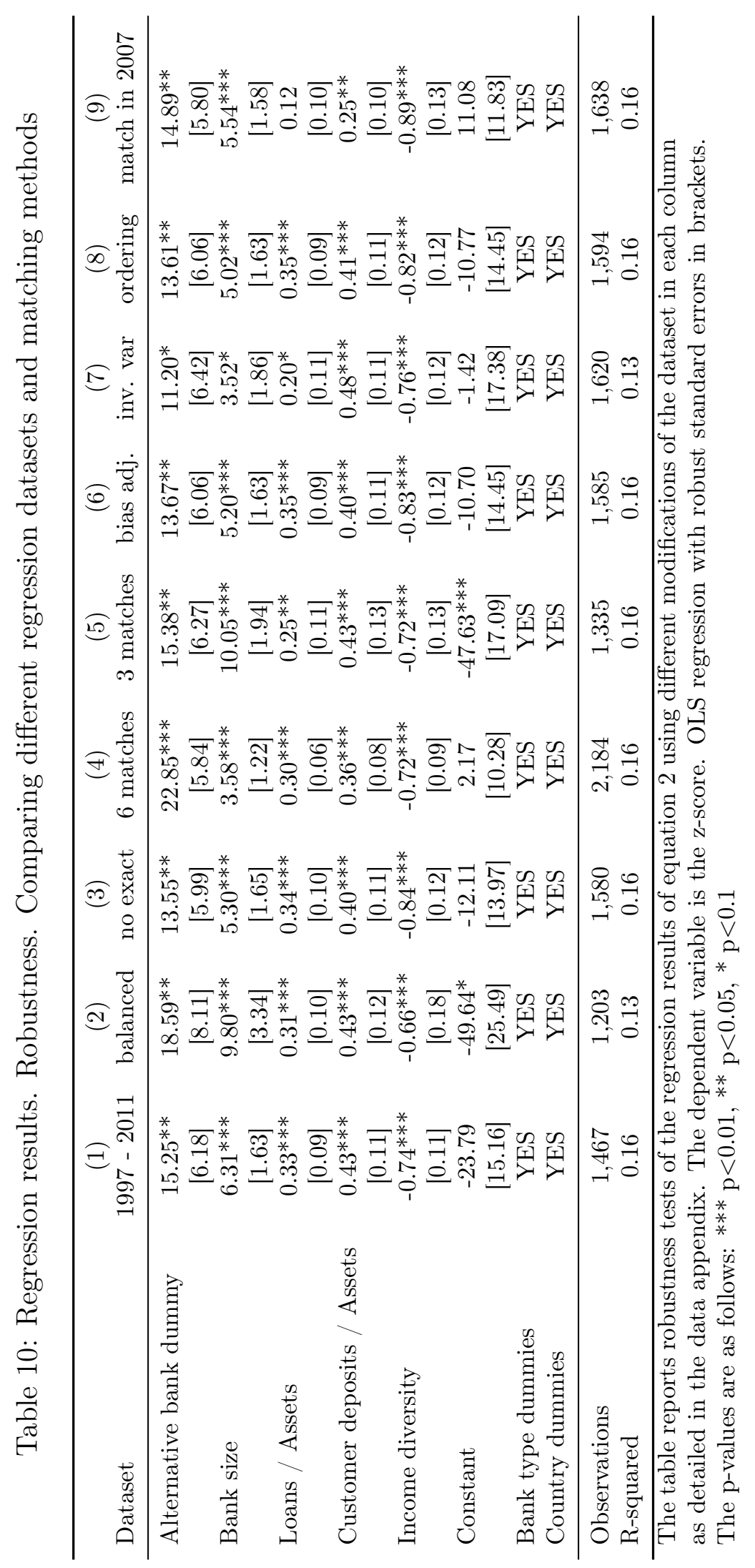


Table 11: Regression Results. Alternative banks in the global financial crisis.

\begin{tabular}{|c|c|c|c|c|c|c|}
\hline Crisis measure & $\begin{array}{l}(1) \\
\text { None }\end{array}$ & $\begin{array}{l}(2) \\
\text { None }\end{array}$ & $\begin{array}{c}(3) \\
\text { Crisis } \\
\text { Intensity }\end{array}$ & $\begin{array}{c}(4) \\
\text { Crisis } \\
\text { Intensity }\end{array}$ & $\begin{array}{c}(5) \\
\text { Crisis } \\
\text { Dummy }\end{array}$ & $\begin{array}{c}(6) \\
\text { Crisis } \\
\text { Dummy }\end{array}$ \\
\hline Alternative bank dummy & $\begin{array}{l}-1.00 \\
{[0.67]}\end{array}$ & $\begin{array}{l}-0.73 \\
{[0.63]}\end{array}$ & $\begin{array}{c}-1.64^{* *} \\
{[0.68]}\end{array}$ & $\begin{array}{c}-1.43^{* *} \\
{[0.66]}\end{array}$ & $\begin{array}{c}-1.69^{* *} \\
{[0.69]}\end{array}$ & $\begin{array}{c}-1.49^{* *} \\
{[0.69]}\end{array}$ \\
\hline Crisis intensity & & & $\begin{array}{c}-0.27^{*} \\
{[0.15]}\end{array}$ & $\begin{array}{c}-0.33^{*} \\
{[0.17]}\end{array}$ & & \\
\hline Int. Crisis Intensity* Alt. Bank & & & $\begin{array}{l}1.12^{* *} \\
{[0.52]}\end{array}$ & $\begin{array}{l}1.20^{*} \\
{[0.62]}\end{array}$ & & \\
\hline Crisis Dummy & & & & & $\begin{array}{l}-0.73 \\
{[0.70]}\end{array}$ & $\begin{array}{l}-0.92 \\
{[0.74]}\end{array}$ \\
\hline Int. Crisis Dummy*Alt.Bank & & & & & $\begin{array}{c}3.69^{* *} \\
{[1.76]}\end{array}$ & $\begin{array}{l}3.86^{*} \\
{[2.01]}\end{array}$ \\
\hline Bank size & $\begin{array}{c}-2.57^{* * *} \\
{[0.44]}\end{array}$ & $\begin{array}{c}-1.74^{* * *} \\
{[0.29]}\end{array}$ & $\begin{array}{c}-2.62^{* * *} \\
{[0.44]}\end{array}$ & $\begin{array}{c}-1.77^{* * *} \\
{[0.29]}\end{array}$ & $\begin{array}{c}-2.61^{* * *} \\
{[0.44]}\end{array}$ & $\begin{array}{c}-1.75^{* * *} \\
{[0.29]}\end{array}$ \\
\hline Loans / Assets & $\begin{array}{c}-0.13^{* * *} \\
{[0.02]}\end{array}$ & $\begin{array}{c}-0.10^{* * *} \\
{[0.02]}\end{array}$ & $\begin{array}{c}-0.13^{* * *} \\
{[0.02]}\end{array}$ & $\begin{array}{c}-0.10^{* * *} \\
{[0.02]}\end{array}$ & $\begin{array}{c}-0.13^{* * *} \\
{[0.02]}\end{array}$ & $\begin{array}{c}-0.11^{* * *} \\
{[0.02]}\end{array}$ \\
\hline Customer deposits / Assets & $\begin{array}{l}-0.02 \\
{[0.02]}\end{array}$ & $\begin{array}{c}-0.06^{* *} \\
{[0.03]}\end{array}$ & $\begin{array}{l}-0.02 \\
{[0.02]}\end{array}$ & $\begin{array}{c}-0.06^{* *} \\
{[0.03]}\end{array}$ & $\begin{array}{l}-0.02 \\
{[0.02]}\end{array}$ & $\begin{array}{c}-0.06^{* *} \\
{[0.03]}\end{array}$ \\
\hline Income diversity & $\begin{array}{c}0.01 \\
{[0.02]}\end{array}$ & $\begin{array}{c}0.02 \\
{[0.03]}\end{array}$ & $\begin{array}{c}0.02 \\
{[0.02]}\end{array}$ & $\begin{array}{c}0.02 \\
{[0.03]}\end{array}$ & $\begin{array}{c}0.02 \\
{[0.02]}\end{array}$ & $\begin{array}{c}0.02 \\
{[0.03]}\end{array}$ \\
\hline Constant & $\begin{array}{c}43.86^{* * *} \\
{[4.02]}\end{array}$ & $\begin{array}{c}39.83^{* * *} \\
{[4.12]}\end{array}$ & $\begin{array}{c}44.02^{* * *} \\
{[4.02]}\end{array}$ & $\begin{array}{c}39.90^{* * *} \\
{[4.11]}\end{array}$ & $\begin{array}{c}44.22^{* * * *} \\
{[4.05]}\end{array}$ & $\begin{array}{c}40.08^{* * *} \\
{[4.16]}\end{array}$ \\
\hline Bank type dummies & YES & YES & YES & YES & YES & YES \\
\hline Country dummies & YES & NO & YES & $\mathrm{NO}$ & YES & NO \\
\hline Observations & 522 & 522 & 522 & 522 & 522 & 522 \\
\hline R-squared & 0.39 & 0.30 & 0.40 & 0.31 & 0.39 & 0.31 \\
\hline
\end{tabular}

This table reports the regression estimates of equation 2 in columns (1) and (2). Columns (3-6) report regression estimates of equation 4 which includes a measure of economic crisis as detailed in the header. The dependent variable is the Regulatory Capital Ratio. OLS regression with robust standard errors in brackets. The p-values are as follows: ${ }^{* * *} \mathrm{p}<0.01,{ }^{* *} \mathrm{p}<0.05,{ }^{*} \mathrm{p}<0.1$ 


\section{References}

Abadie, A., D. Drukker, J. L. Herr, And G. W. Imbens (2004): "Implementing matching estimators for average treatment effects in Stata," Stata Journal, 4, 290311.

Abadie, A. And G. W. Imbens (2002): "Simple and Bias-Corrected Matching Estimators for Average Treatment Effects," Working Paper 283, NBER.

Acharya, V. V., I. Hasan, And A. Saunders (2006): "Should Banks be diversified? Evidence from Individual Bank Loan Portfolios," The Journal of Business, 79, 13551412.

Angrist, J. D. And J.-S. PISChke (2008): Mostly harmless econometrics: An empiricist's companion, Oxford: Princeton University Press.

BAlli, H. O. And B. E. SøRensen (2013): "Interaction effects in econometrics," Empirical Economics, 45, 583-603.

Becchetti, L. (2011): "Why do we need social banking?" in Social banks and the future of sustainable finance, ed. by S. Remer and O. Weber, Taylor \& Francis.

Becchetti, L., R. Ciciretti, A. Dalo, And S. Herzel (2014): "Socially Responsible and Conventional Investment Funds: Performance Comparison and the Global Financial Crisis," Working paper no. 310, CEIS.

Becchetti, L. And M. M. Garcia (2008): "Do Collateral Theories Work in Social Banking?" CEIS Working Paper, Vol. 6, Issue 9, No. 131., CEIS.

Becchetti, L., A. Palestini, N. Solferino, And M. E. Tessitore (2013): "The Socially Responsible Choice in a Duopolistic Market: A Dynamic Model of 'Ethical Product' Differentiation," SSRN Scholarly Paper ID 2240975, SSRN.

Beck, T., A. DemirgüÇ-Kunt, And O. Merrouche (2013): "Islamic vs. conventional banking: Business model, efficiency and stability," Journal of Banking $\&$ Finance, 37, 433-447. 
Beck, T., H. Hesse, T. Kick, and N. von Westernhagen (2009): "Bank Ownership and Stability: Evidence from Germany," Mimeo.

Benedikter, R. (2011): Social Banking and Social Finance, Springer.

Bourkhis, K. AND M. S. NABI (2013): "Islamic and conventional banks' soundness during the 2007-2008 financial crisis," Review of Financial Economics, 22, 68-77.

Boyd, J. H. And D. E. Runkle (1993): "Size and performance of banking firms: Testing the predictions of theory," Journal of Monetary Economics, 31, 47-67.

Brambor, T., W. R. Clark, and M. Golder (2006): "Understanding Interaction Models: Improving Empirical Analyses," Political Analysis, 14, 63-82.

Buch, C. M. And K. Neugebauer (2011): "Bank-specific shocks and the real economy," Journal of Banking \&f Finance, 35, 2179-2187.

ČIHAK, M. And H. Hesse (2010): "Islamic Banks and Financial Stability: An Empirical Analysis," Journal of Financial Services Research, 38, 95-113.

Cornée, S. And A. Szafarz (2013): "Vive la Différence: Social Banks and Reciprocity in the Credit Market," Journal of Business Ethics, 125, 361-380.

DemirgüÇ-Kunt, A., E. Detragiache, and P. Gupta (2006): "Inside the crisis: An empirical analysis of banking systems in distress," Journal of International Money and Finance, 25, 702-718.

Duprey, T. AND M. LÉ (2014): "Bankscope Dataset: Getting Started," SSRN Scholarly Paper ID 2191449, Paris School of Economics.

Fessmann, M. (2013): "Ethisch-Ökologisches Banking vor dem Hintergrund der jüngsten Finanzkrise," Vierteljahrshefte zur Wirtschaftsforschung / Quarterly Journal of Economic Research, 82, 89-106.

Fitch Ratings And Bureau van Dijk (2009): "The Fitch Universal Format on BankScope," Available from: http://www.bvd.co.uk/bankscope/bankscope.pdf. 
Hamilton, L. C. (2012): Statistics with Stata: Version 12, Boston, MA: Duxbury, revised ed.

HARvey, B. (1995): "Ethical banking: The case of the Co-operative bank," Journal of Business Ethics, 14, 1005-1013.

Hasan, M. And J. Dridi (2011): "The Effects of the Global Crisis on Islamic and Conventional Banks: A Comparative Study," Journal of International Commerce, Economics and Policy, 02, 163-200.

Hesse, H. And M. ČIHAK (2007): "Cooperative Banks and Financial Stability," IMF working paper no. 07/02., IMF.

HÄrdle, W. K. ANd L. Simar (2012): Applied Multivariate Statistical Analysis, Heidelberg ; New York: Springer, 3rd ed ed.

Imbens, G. W. (2014): "Matching Methods in Practice: Three Examples," Working Paper 19959, NBER.

JokipiI, T. AND A. MiLne (2011): "Bank capital buffer and risk adjustment decisions," Journal of Financial Stability, 7, 165-178.

KÖHLER, M. (2010): "ZEW Finanzmarktreport. Sonderfrage Social Banking." Available from: http://ftp.zew.de/pub/zew-docs/frep/072010.pdf.

L (2014): "Does non-interest income make banks more risky? Retail- vs. Investment-Oriented Banks," Review of Financial Economics, 23, 182 Ū193.

— (2015): "Which banks are more risky? The impact of business models on bank stability," Journal of Financial Stability, 16, 195 Ü212.

LAeven, L. AND R. LeVine (2007): "Is there a diversification discount in financial conglomerates?" Journal of Financial Economics, 85, 331-367.

- (2009): "Bank governance, regulation and risk taking," Journal of Financial Economics, 93, 259-275. 
Remer, S. (2011): "Social banking at the crossroads," in Social banks and the future of sustainable finance, ed. by S. Remer and O. Weber, Taylor \& Francis.

RéSeau Financement Alternatif (2006): "Rapport Final du projet Fineurosol," Available from: http://www.fineurosol.org/epargne-solidaire/fineurosol-unprojet-europeen-pour-l-epargne-solidaire,fr,153.html.

San-Jose, L., J. L. Retolaza, And J. Gutierrez-Goiria (2011): "Are Ethical Banks Different? A Comparative Analysis Using the Radical Affinity Index," Journal of Business Ethics, 100, 151-173.

Scheire, C. And S. De Maertelaere (2009): "Banking to make a difference. A preliminary research paper on the business models of the founding member banks of the Global Alliance for Banking on Values." Research paper, Artevelde University College Gent.

Von Passavant, C. (2011): "Inside social banks," in Social banks and the future of sustainable finance, ed. by S. Remer and O. Weber, Taylor \& Francis.

Weber, O. And S. REMER, eds. (2011): Social Banks and the Future of Sustainable Finance, Routledge.

ZEB (2012): "Social Banking Study. Management Summary," Available from: https://www.zeb.de/de/aktuelles/zeb-social-banking-study-2012.html. 